\title{
The SGLT-2 inhibitor empagliflozin improves myocardial strain, reduces cardiac fibrosis and pro-inflammatory cytokines in non-diabetic mice treated with doxorubicin
}

\author{
Vincenzo Quagliariello ${ }^{{ }^{*}} \mathbb{D}$, Michelino De Laurentiis ${ }^{2}$, Domenica Rea ${ }^{3}$, Antonio Barbieri ${ }^{3}$, Maria Gaia Monti ${ }^{4}$, \\ Andreina Carbone ${ }^{1}$, Andrea Paccone ${ }^{1}$, Lucia Altucci ${ }^{5}$, Mariarosaria Conte ${ }^{5}$, Maria Laura Canale ${ }^{6}$, \\ Gerardo Botti ${ }^{7}$ and Nicola Maurea ${ }^{1 *}$
}

\begin{abstract}
Background: Empagliflozin (EMPA), a selective inhibitor of the sodium glucose co-transporter 2, reduced the risk of hospitalization for heart failure and cardiovascular death in type 2 diabetic patients in the EMPA-REG OUTCOME trial. Recent trials evidenced several cardio-renal benefits of EMPA in non-diabetic patients through the involvement of biochemical pathways that are still to be deeply analysed. We aimed to evaluate the effects of EMPA on myocardial strain of non-diabetic mice treated with doxorubicin (DOXO) through the analysis of NLRP3 inflammasome and MyD88-related pathways resulting in anti-apoptotic and anti-fibrotic effects.

Methods: Preliminary cellular studies were performed on mouse cardiomyocytes (HL-1 cell line) exposed to doxorubicin alone or combined to EMPA. The following analysis were performed: determination of cell viability (through a modified MTT assay), study of intracellular ROS production, lipid peroxidation (quantifying intracellular malondialdehyde and 4-hydroxynonenal), intracellular $\mathrm{Ca}^{2+}$ homeostasis. Moreover, pro-inflammatory studies were also performed: expression of NLRP3 inflammasome, MyD88 myddosome and p65/NF-kB associated to secretion of cytokines involved in cardiotoxicity (Interleukins 1 $\beta, 8,6$ ). C57BI/6 mice were untreated (Sham, $n=6$ ) or treated for 10 days with doxorubicin (DOXO, $n=6)$, EMPA (EMPA, $n=6$ ) or doxorubicin combined to EMPA (DOXO-EMPA, $n=6$ ). DOXO was injected intraperitoneally. Ferroptosis and xanthine oxidase were studied before and after treatments. Cardiac function studies, including EF, FS and radial/longitudinal strain were analysed through transthoracic echocardiography (Vevo 2100). Cardiac fibrosis and apoptosis were histologically studied through Picrosirius red and TUNEL assay, respectively and quantified through pro-collagen-1a1, MMP-9 and Caspase-3 expression. Tissue NLRP3, MyD88 and cytokines were also quantified before and after treatments through ELISA methods.
\end{abstract}

Results: Cardiomyocytes exposed to doxorubicin increased the intracellular $\mathrm{Ca}^{2+}$ content and expression of several pro-inflammatory markers associated to cell death; co-incubation with EMPA reduced significantly the magnitude of the effects. In preclinical study, EMPA increased EF and FS compared to DOXO groups $(p<0.05)$, prevented the

\footnotetext{
*Correspondence: quagliariello.enzo@gmail.com; n.maurea@istitutotumori.na.it

1 Division of Cardiology, Istituto Nazionale Tumori-IRCCS-Fondazione G.

Pascale, Naples, Italy

Full list of author information is available at the end of the article
} original author(s) and the source, provide a link to the Creative Commons licence, and indicate if changes were made. The images or other third party material in this article are included in the article's Creative Commons licence, unless indicated otherwise in a credit line to the material. If material is not included in the article's Creative Commons licence and your intended use is not permitted by statutory regulation or exceeds the permitted use, you will need to obtain permission directly from the copyright holder. To view a copy of this licence, visit http://creativecommons.org/licenses/by/4.0/. The Creative Commons Public Domain Dedication waiver (http://creativeco mmons.org/publicdomain/zero/1.0/) applies to the data made available in this article, unless otherwise stated in a credit line to the data. 
reduction of radial and longitudinal strain after 10 days of treatment with doxorubicin (RS) 30.3\% in EMPA-DOXO vs $15.7 \%$ in DOXO mice; LS - 17\% in EMPA-DOXO vs $-11.7 \%$ in DOXO mice ( $p<0.001$ for both). Significant reductions in ferroptosis, xanthine oxidase expression, cardiac fibrosis and apoptosis in EMPA associated to DOXO were also seen. A reduced expression of pro-inflammatory cytokines, NLRP3, MyD88 and NF-kB in heart, liver and kidneys was also seen in DOXO-EMPA group compared to DOXO $(p<0.001)$.

Conclusion: EMPA reduced ferroptosis, fibrosis, apoptosis and inflammation in doxorubicin-treated mice through the involvement of NLRP3 and MyD88-related pathways, resulting in significant improvements in cardiac functions. These findings provides the proof of concept for translational studies designed to reduce adverse cardiovascular outcomes in non-diabetic cancer patients treated with doxorubicin.

Keywords: EMPA, Cardio-Oncology, Doxorubicin, Inflammation, Interleukins

\section{Background}

Doxorubicin (DOXO) induced-cardiotoxicity is a wellknown adverse event in cancer patients [1,2]. As recently described in literature, DOXO-induced cardiotoxicity involves pro-inflammatory interleukins, pro-oxidative markers, ferroptosis, topoisomerase II $\beta$ inhibition and mitochondrial dysfunction [3-5]. Improvement in knowledge of DOXO-induced pathophysiology pushes the search for new potential cardioprotective agents able to prevent cardiotoxic events.

EMPA (EMPA) (Jardiance, Boehringer Ingelheim) is a sodium-glucose cotransporter 2 (SGLT-2) inhibitor with hypoglycaemic and anti-oxidant effects [6]. The beneficial properties of EMPA involves both indirect and direct effects in heart tissue, such as the reduction of 8-iso prostaglandin $\mathrm{f} 2 \alpha$ (a product of lipid peroxidation), blunted the activation of mitogenic stress pathways such ERKs, JNKs, and p38 MAPKs [7].

In EMPA-REG Outcome trial, which enrolled about 7000 patients affected by type 2 diabetes, deaths from cardiovascular causes were $3.7 \%$ in patients treated with EMPA versus $5.9 \%$ in patients receiving placebo, which corresponds to a relative risk reduction of cardiovascular diseases of 38\% [8-10]. Interestingly, EMPA exerts beneficial effects also in non-diabetic patients, as described in recent clinical trials named EMPEROR-Reduced/preserved [11].

Given the crucial role of the heart pro-inflammatory microenvironment in the genesis of DOXO-related cardiotoxicity, we evaluated the impact of EMPA on DOXOinduced cardiotoxicity and studied the putative beneficial effects on fibrosis, cardiac functions, and expression of pro-inflammatory cytokines both in cardiomyocytes and mouse models.

\section{Methods}

\section{Cell viability}

Firstly, we aimed to evaluate the effects of EMPA combined to DOXO in cell cultures of cardiomyocytes (HL-1 adult mouse cells derived from American Type Culture
Collection, Manassas, VA, USA), estrogen-responsive and triple-negative breast cancer cells (MCF-7 and MDA-MB-231 cell lines, derived from American Type Culture Collection, Manassas, VA, USA). To evaluate the cytotoxic or cytoprotective effects of EMPA, the mitochondrial dehydrogenase activity was quantified through a modified MTT [3-(4,5-dimethyldiazol-2-yl)-2,5-diphenyl tetrazolium bromide] method, called MTS assay, according to the manufacturer's instructions (Dojindo Molecular Technologies Inc., Rockville, MD, USA) [12]. Briefly, HL-1 cells were grown in a complete medium constituted by Claycomb medium, $10 \% \mathrm{~V} / \mathrm{v}$ heat-inactivated foetal bovine serum, $2 \mathrm{mM} \mathrm{l-glutamine,} 100 \mathrm{U} / \mathrm{ml}$ penicillin and $100 \mu \mathrm{g} / \mathrm{ml}$ streptomycin in 96-well plates (density of 10,000 cells/well) at $37{ }^{\circ} \mathrm{C}$ in a humidified $5 \% \mathrm{CO}_{2}$ atmosphere. MCF-7 human breast cancer cells $(\mathrm{ER} \alpha+, \mathrm{PR}+, \mathrm{HER} 2-)$ were cultured in Dulbecco's modified Eagle's medium (DMEM) supplemented with 10\% fetal bovine serum (FBS), $2 \mathrm{mM}$ glutamine, 100 units $/ \mathrm{mL}$ penicillin and 100 units $/ \mathrm{mL}$ streptomycin. Triple negative MDA-MB-231 $\left(\right.$ ATCC $^{\circledR}$ HTB- $^{\mathrm{TM}}{ }^{\mathrm{M}}$ ) cells were grown in ATCC-formulated Leibovitz's L-15 Medium supplemented with $10 \%$ fetal bovine serum (FBS) (HyClone ${ }^{\mathrm{TM}}$, GE Healthcare Life Sciences, Milan, Italy) and Penic illin-Streptomycin $\left(100 \mathrm{U} / \mathrm{mL}\right.$, Gibco ${ }^{\circledR}$, Milan, Italy). Cell cultures were maintained in a humidified atmosphere of 95\% air and $5 \% \mathrm{CO} 2$ at $37^{\circ} \mathrm{C}$.

After $24 \mathrm{~h}$ of appropriate growth, cells were exposed to: DOXO (0.1 to $50 \mu \mathrm{M})$; EMPA (50, 100 and $500 \mathrm{nM}$ ); DOXO-EMPA (both drugs combined). Cells were than incubated for $24 \mathrm{~h}$ with each drug under standard growth conditions. Cells were then washed three times with phosphate buffered solution (PBS) at $\mathrm{pH} 7.4$ and then incubated with $100 \mu \mathrm{l}$ of an MTT solution $(0.5 \mathrm{mg} / \mathrm{ml}$ in cell culture medium) for $4 \mathrm{~h}$ at $37{ }^{\circ} \mathrm{C}$. Absorbance readings were acquired at a wavelength of $450 \mathrm{~nm}$ with the Tecan Infinite M200 plate-reader (Tecan Life Sciences Home, Männedorf, Switzerland) using I-control software (Tecan). Relative cell viability (\%) was calculated with the following formula [A]test/[A]control $\times 100$, where 
"[A]test" is the absorbance of the test sample, and "[A] control" is the absorbance of the control cells incubated solely in culture medium.

\section{Quantification of intracellular reactive oxygen species (iROS)}

Quantification of iROS was performed by using a conventional fluorescent probe (DCFH-DA) as described elsewhere [13]. Cardiomyocytes $\left(5 \times 10^{3}\right.$ cells/well) were seeded in a 24-well plate and allowed to grow for $24 \mathrm{~h}$; after, cells were pre-treated or not with EMPA at 10, 50 and $500 \mathrm{nM}$ for $4 \mathrm{~h}$. Cardiomyocytes pre-treated with gallic acid $(50 \mu \mathrm{M})$ served as positive control. After, cells were incubated with $5 \mu \mathrm{M}$ DCFH-DA in PBS for $30 \mathrm{~min}$. Then, DCFH-DA was removed from each well and cells were stimulated with $40 \mathrm{ng} / \mathrm{mL}$ of lipopolysaccharides (LPS, as internal control) or DOXO at $100 \mathrm{nM}$ for $12 \mathrm{~h}$. Cell fluorescence was measured using a microplate spectrofluorometer. Intracellular antioxidant activity was expressed as percentage of control cells. The concentration of DOXO used were within the range of 25-250 nM, calculated for steady-state plasma concentrations of DOXO, intravenously administered, in cancer patients at the common therapeutic dosage of $15-90 \mathrm{mg} / \mathrm{m}^{2}[14$, 15].

\section{Lipid peroxidation}

To study the putative anti-oxidant effects of EMPA, HL-1 cells were grown as described above. Subsequently, $5 \times 10^{3}$ cells/well were seeded in a 24-well plate and allowed to grow for $24 \mathrm{~h}$ and exposed to DOXO (100 nM) or LPS (40 ng/ml, as positive control in inflammation in human cells, as described by our group $[12,13])$ for $6 \mathrm{~h}$ or pre-treated for $4 \mathrm{~h}$ with EMPA (10, 50 and $500 \mathrm{nM})$ or with gallic acid $(50 \mu \mathrm{M})$ as anti-oxidant positive control. After centrifugation at $800 \times \mathrm{g}$ for $5 \mathrm{~min}$, the supernatant was evaluated for malondialdehyde (MDA) and 4-hydroxy 2-hexenal (4-HNA) using commercial kits with a spectrophotometer according to the manufacturer's protocols (Sigma Aldrich, Milan, Italy).

\section{Nitric oxide assay}

To evaluate the effects of EMPA on the release of nitric oxide from HL-1 cells, we analysed the release of nitrite, which is a stable product of nitric oxide in aqueous medium, using the Griess Reagent System (Promega, Madison, WI, USA) as described elsewhere [16]. Cells were treated as described before; after treatment, the culture medium was then mixed with an equal volume of sulfanylamide solution $(1 \% \mathrm{v} / \mathrm{v}$ in $5 \% \mathrm{v} / \mathrm{v}$ phosphoric acid) and of $\mathrm{N}$-1-naphtylethylenediamine dihydrochloride solution $(0.1 \% \mathrm{v} / \mathrm{v}$ in water). Absorbance was measured at $540 \mathrm{~nm}$ with a spectrophotometer.

\section{Intracellular $\mathrm{Ca}^{2+}$ assay}

Cardiomyocytes exposed to DOXO increases the intracellular calcium concentration due overproduction of iROS [4]. We quantified the intracellular $\mathrm{Ca}^{2+}$ in HL-1 cells by using the fluorescence dye Fluo-3 AM, according to the manufacturer's protocol. Cardiomyocytes were untreated or treated as described before. After incubation, cells were loaded with $5 \mu \mathrm{M}$ Fluo-3 $\mathrm{AM}$ at $37{ }^{\circ} \mathrm{C}$ for $30 \mathrm{~min}$ in the dark, and then washed three times with PBS ( $\mathrm{pH} 7.4$ ) to remove the excess dye. Fluo-3 chelated with calcium produces fluorescence that was quantified with a spectrofluorometer at excitation and emission wavelengths of $488 \mathrm{~nm}$ and $525 \mathrm{~nm}$, respectively.

\section{Anti-inflammatory studies \\ Cytokine assay}

The expression of IL- 6 , IL- 8 and IL- $1 \beta$ was performed through ELISA method, as described elsewhere [12]. Briefly, HL-1 cells were grown as described above. After incubation for $24 \mathrm{~h}$ and starvation in serumfree medium for $2.5 \mathrm{~h}, \mathrm{HL}-1$ cells were treated or not with EMPA in doses ranging from 10 to $500 \mathrm{nM}$ for $4 \mathrm{~h}$ before exposure to LPS (40 $\mathrm{ng} / \mathrm{ml})$ or DOXO $(100 \mathrm{nM})$ for $12 \mathrm{~h}$ to stimulate inflammation. After exposure, supernatants were collected, centrifuged to pellet any detached cells and measured using IL-1 $\beta$, IL- 6 and IL- 8 ELISA kits according to the manufacturer's instructions (Sigma Aldrich, Milan, Italy).

\section{Leukotriene B4 assay}

To quantify leukotrienes B4 (LTB4), cardiomyocytes were treated as described before; after treatments, cells were incubated at $37{ }^{\circ} \mathrm{C}$ for $30 \mathrm{~min}$ with serum-free medium containing a solution constituted by $5 \mu \mathrm{M}$ of the calcium ionophore $\mathrm{A} 23187,1.6 \mathrm{mM}$ of $\mathrm{CaCl} 2$ and $10 \mu \mathrm{M}$ of arachidonic acid. Arachidonate was used as precursor of leukotriene synthesis. Immuno reactive LTB4 was quantified with an ELISA procedure (Cayman Chemical) according to the supplier's instructions [17].

\section{p65/NF-kB expression}

Cardiomyocytes were treated with DOXO (100 nM) or EMPA $(10,50$ and $500 \mathrm{nM})$ or DOXO and EMPA for $24 \mathrm{~h}$. After, nuclear extracts were analysed using the TransAM p65/NF-kB transcription factor assay kit (Active Motif, Carlsbad, CA, USA), according to the manufacturer's recommendations [18]. Data were expressed as the percentage of p65/NF-kB DNA binding versus control (untreated) cells. 


\section{NLRP3 and MyD88 expression}

Cardiomyocytes were treated with DOXO (100 nM) or EMPA (10, 50 and $500 \mathrm{nM})$ or DOXO and EMPA for $24 \mathrm{~h}$. After treatments, cells were harvested and lysed in complete lyses buffer (50 mM Tris-HCl, pH 7.4, $1 \mathrm{mM}$ EDTA, $100 \mathrm{mM} \mathrm{NaCl}, 20 \mathrm{mM} \mathrm{NaF}, 3 \mathrm{mM} \mathrm{Na} 3$ VO4, $1 \mathrm{mM}$ PMSF, and protease inhibitor cocktail). After centrifugation, supernatants were collected and treated to the quantification of MyD88 (Mouse MyD88 ELISA Kit, Abcam, Italy) and NLRP3 (Mouse NLRP3 ELISA Kit, Aviva Systems Biology). For mouse MyD88 ELISA the sensitivity was $<10 \mathrm{pg} / \mathrm{ml}$ and range of detection was $156-10,000 \mathrm{pg} / \mathrm{ml}$; for mouse NLRP3 ELISA assay, the sensitivity was $<0.078 \mathrm{ng} / \mathrm{mL}$ and range of detection was $0.156-10 \mathrm{ng} / \mathrm{mL}$.

\section{Confocal laser scanning microscope (CLSM) imaging}

HL-1 cells were cultured as described above. After, $5 \times 10^{3}$ cells/well were seeded in a 24-well plate and allowed to grow for $24 \mathrm{~h}$ and untreated (control) or treated with DOXO (100 nM) or EMPA (100 nM) or DOXO (100 nM) combined with EMPA (100 nM) for one day. Then, cells were thoroughly rinsed three times with PBS and fixed with $2.5 \%$ glutaraldehyde in PBS for $20 \mathrm{~min}$, as described elsewhere [19]. After washing three times with PBS, cells were permeabilized with $0.1 \%$ Triton-X100 in PBS for $10 \mathrm{~min}$ and then washed three times with PBS. Subsequently, cells were blocked with $1 \%$ BSA in PBS for 20 min. After three washes with PBS, cells were incubated with a Rabbit polyclonal antibody against p65/NF-kB (clone ab16502 Abcam) diluted 1:200 in $1 \% \mathrm{BSA}$ for $1 \mathrm{~h}$. After washing, cells were incubated for $1 \mathrm{~h}$ with Goat Anti-Rabbit secondary antibody IgG H\&L (FITC) (clone ab6717, AbCam) diluted 1:1000 in $1 \%$ BSA. Nuclear staining was obtained through the use of NUCLEAR-ID ${ }^{\circledR}$ Red DNA stain (Enzo Life Technology, Milan, Italy) diluted 1:2000 in PBS for 15-30 min at $37{ }^{\circ} \mathrm{C}$. After washing in PBS, cells were blocked with $1 \%$ BSA in PBS for 20 min. A confocal microscope (C1 Nikon) equipped with EZ-C1 software for data acquisition was used $(60 \times$ oil immersion objective). Expression of p65/NF-kB and nucleus were imaged through excitation/emission at $492 / 518 \mathrm{~nm}$ and $566 / 650 \mathrm{~nm}$, respectively.

\section{Animal models}

Twenty-four female $\mathrm{C} 57 \mathrm{Bl} / 6$ mice (6 weeks/age) were purchased from Harlan, San Pietro al Natisone (Italy). Mice were housed 6 per cage and maintained on a 12-h light to $12 \mathrm{~h}$ dark cycle (lights on at $7.00 \mathrm{am}$ ) in a temperature-controlled room $\left(22 \pm 2{ }^{\circ} \mathrm{C}\right)$ and with food and water ad libitum. Preclinical experimental protocols were in accordance with EU Directive 2010/63/EU for animal experiments, and Italian D.L.vo 26/2014 low; were approved by Ministry of Health with authorization number 1467/17-PR of the 13-02-2017, and institutional ethics committees: Organismo preposto al benessere degli animali (OPBA). After 1 week of growth, mice were randomized for weight-adjusted treatment. Mice were divided in 4 experimental groups $(n=6 /$ group) (i) $100 \mu \mathrm{l}$ saline solution (Sham); (ii) DOXO at $2.17 \mathrm{mg} / \mathrm{kg} /$ day through intraperitoneal administration (i.p); (iii) EMPA $10 \mathrm{mg} / \mathrm{kg} /$ day through oral gavage; (iv) EMPA/DOXO in combination (at the same concentration of each drug tested alone). Treatments were performed according to our protocol recently published were we evaluated the cardioprotective effects of Ranolazine against cardiotoxicity of doxorubicin for 10 days [20]; in fact, also in this case, in group of combinatorial treatment EMPA/DOXO, mice were treated with EMPA alone for 3 days and the remaining 7 days also in combination to DOXO. Another work investigated on the initial damages of doxorubicin and trastuzumab administration at low doses in mice with significant changes in cardiac apoptosis, necrosis and fibrosis leading to reduced cardiac functions after 7 days of treatment [21]. Notably, used short-term treatment of doxorubicin is more than sufficient to evaluate myocardial dysfunction in mice; in fact, in the same experimental procedure showed by Tocchetti $G$ et al. [20], and Fedele et al. [22] in C57BL6 mice, doxorubicin treatment for 7 days produced left ventricular dilation and decreased echo-measured fractional shortening (FS) as well as detectable apoptosis and inflammation in myocardial tissues. Blood glucose determination were performed via puncture of the tail vein before and after treatments by a glucometer (Model NC).

\section{Transthoracic echocardiography}

To assess cardiac function in vivo we performed noninvasive transthoracic echocardiography in sedated mice using a Vevo 2100 high-resolution imaging system (40$\mathrm{MHz}$ transducer; Visualsonics, Toronto, ON, Canada) as described in literature [21, 23]. Mice were anaesthetized with tiletamine $(0.09 \mathrm{mg} / \mathrm{g})$, zolazepam $(0.09 \mathrm{mg} / \mathrm{g})$, and $0.01 \%$ atropine $(0.04 \mathrm{~mL} / \mathrm{g})$. After, animals were sedated and placed in supine position on a temperature-controller surgical table to maintain rectal temperature at $37^{\circ} \mathrm{C}$, continual ECG monitoring was obtained via limb electrodes. Cardiac function was evaluated at basal conditions and at 2 and 10 days of treatments. Left ventricular echocardiography was assessed in parasternal long-axis views at a frame rate of $233 \mathrm{~Hz}$. Notably, we measured the strain in parasternal views because the apical view is difficult to perform in small animal [24]; this method was in line with other studies for STE analyses that were performed on parasternal long-axis B-mode loops using 
a VisualSonics Vevo 2100 system (VisualSonics) [25-27]. Image depth, width, and gain settings were optimized to improve image quality. End-systole and end-diastole dimensions were defined as the phases corresponding to the ECG T wave, and to the R wave, respectively. M-mode LV internal dimensions, diastolic (LVID,d) and LV internal dimensions, systolic (LVID,s) were averaged from 3 to 5 beats. LVID,d and LVID,s were measured from the LV M-mode at the mid papillary muscle level. Fractional shortening percentage (\% FS) was calculated as [(LVID, d-LVID, s)/LVID, d] X 100, and ejection fraction percentage (\% EF) was calculated as [(EDvol-ESvol)/EDvol] $\mathrm{X} 100$. The strain was expressed as percentage. The analysis start with acquired B-mode loops and were imported into the Vevo Strain software. Three consecutive cardiac cycles were selected and the endocardium traced. Upon adequate tracing of the endocardium, an epicardial trace was added. ST based strain allowed assessment of strains specific to 6 myocardial segments per LV view. Internally, 10 or plus points were measured for each of the $6 \mathrm{seg}$ ments, resulting in 48 data points in total. Strain and SR are useful in the detection of regional myocardial function. The strain is evaluated on long-axis views as well as: radial and longitudinal. Radial strain (RS), defined as the percent change in myocardial wall thickness is a positive curve reflecting increasing myocardial thickness during systole and diminishing wall thickness during diastole and represent myocardial deformation toward the centre of the LV cavity. Longitudinal strain (LS) detects the percent change in length of the ventricle, typically measured from the endocardial wall in the long-axis view. Myocardial deformation rate, expressed in $1 / \mathrm{s}$, was also calculated. Notably, we measure LV, diastolic and systolic volumes in the one-dimensional view following the proper instructions of "Small Animal Echocardiography using the Vevo ${ }^{\circledR} 2100$ Imaging System" [28] and also in agree with our previous similar work [20].

\section{Isolation of cytosolic and mitochondrial fractions in heart tissue}

Isolation of cytosolic and mitochondrial fractions was performed using heart tissues wherein the Mitochondria/Cytosol Fractionation Kit (ab65320, Abcam) was used for cytosol fractionation and the Mitochondria Isolation Kit (P507L, $101 \mathrm{Bio})$ for mitochondrial fractionation in accordance with the manufacturer's instructions.

\section{Ferroptosis assay: measurements of mitochondrial lipid peroxidation using MitoPeDPP and MDA content in cytosolic and mitochondrial fractions}

Increasing evidence indicates that ferroptosis plays a critical role in doxorubicin-induced cardiotoxicity [2931]; therefore, we aimed to test the effect of EMPA on ferroptosis during DOXO treatment. Mitochondrial lipid peroxidation was measured using MitoPeDPP test (a fluorescence probe that specifically reacts with lipid peroxides in the mitochondrial inner membrane (Dojindo). Briefly, mitochondrial fraction was incubated for $30 \mathrm{~min}$ at $37{ }^{\circ} \mathrm{C}$ in a solution at $0.5 \mu \mathrm{M}$ MitoPeDPP. After incubation, lipid peroxides in the mitochondrial inner membrane were fluorometrically measured (excitation $452 \mathrm{~nm}$ and emission at $470 \mathrm{~nm}$ ) using a Tecan Infinite M200 plate-reader (Tecan Life Sciences Home, Männedorf, Switzerland) equipped with a I-control software (Tecan). MDA levels in cytosolic and mitochondrial fraction of heart tissues were measured using commercial kit (MDA ELISA kit; Sigma Aldrich; Milan, Italy) were lipid peroxidation is determined by the reaction of MDA with thiobarbituric acid (TBA) to form a colorimetric $(532 \mathrm{~nm}) /$ fluorometric $(\lambda \mathrm{ex}=532 / \lambda \mathrm{em}=553 \mathrm{~nm})$ product, proportional to the MDA content.

\section{Xanthine oxidase activities}

The recent study by Tanaka et al. showed that the increased oxidative stress induced by tissue xanthine oxidase activation is deeply involved in doxorubicininduced cardiotoxicity [31]. The xanthine oxidase activities in heart tissues were measured using the horseradish peroxidase-linked Amplex Red fluorescence assay kit (Molecular Probes, Invitrogen Detection Technologies), according to the manufacturer's instructions. In brief, heart tissues were homogenized in T-PER Tissue Protein Extraction (Thermo Fisher Scientific, USA) and centrifuged at $14,000 \mathrm{~g}$ for $10 \mathrm{~min}$ at $4{ }^{\circ} \mathrm{C}$. Supernatant was added to a working solution composed by Amplex Red reagent $(100 \mu \mathrm{M})$, xanthine $(0.2 \mathrm{mM})$, and horseradish peroxidase type $(0.4 \mathrm{U} / \mathrm{ml})$, incubated at $37{ }^{\circ} \mathrm{C}$ for 30 min; produced $\mathrm{H}_{2} \mathrm{O}_{2}$ was measured. Fluorescence readings were made in triplicate in a 96-well plate at Ex/ $\mathrm{Em}=540 / 590 \mathrm{~nm}$. The XO activity was corrected by the protein concentration of the supernatant measured by a Bradford assay.

\section{Anti-inflammatory studies in tissue extracts}

After treatments, heart, liver and left kidney were weighed and treated for quantification of cytokines, MyD88 and NLRP3. The heart tissues were cut in transverse section into two parts. The basal parts of the hearts, and the whole liver and left kidney were snap-frozen in dry ice until tissue homogenization, which was carried out in $0.1 \mathrm{M}$ PBS (pH 7.4) containing $1 \%$ Triton X-100, protease inhibitor cocktail and processed using a high intensity ultrasonic liquid processor. The homogenates were centrifuged at $4{ }^{\circ} \mathrm{C}$ and supernatants were used to determine tissue markers. The apical parts of the heart sections were fixed in $10 \%$ neutral buffered formalin for 
$48 \mathrm{~h}$ for the cardiac fibrosis and apoptosis assays Methods for quantification in interleukins in tissue extracts were followed using the appropriate ELISA kits for mouse IL-1 $\beta$, IL- 8 and IL- 6 detections, as used in the cellular experiments, according to the manufacturer's instructions; results are expressed as pg of interleukin/ mg of tissue. The MyD88 and NLRP3 expression in heart tissues were performed through the use of the same kits described for cellular experiments and results are expressed as pg of MyD88 or pg of NLRP3/mg of protein.

\section{Cardiac fibrosis: collagen type l expression in cardiac tissue}

For ex vivo analyses, hearts were excised and fixed in $10 \%$ neutral buffered solution. The myocardial tissue was formalin-fixed and paraffin-embedded for morphometry and immunohistochemistry. General morphology was studied using haematoxylin-eosin staining. To measure collagen content, we deparaffinised $6 \mu \mathrm{m}$-thick cross sections and stained them with Picrosirius red (Carlo Erba Laboratories, Milan, Italy). The collagen volume fraction was expressed as the mean percentage of Picrosirius red-stained tissue areas divided by total tissue area in the same field and was evaluated in 15 fields at $60 \times$ magnification. The positively stained (red) fibrotic area was measured with a computer-assisted image analysis system (Nikon NIS Elements. Nikon Instruments, Melville, NY, USA). To measure capillary density, we incubated sections overnight with biotinylated Bandeira easimplicifolia Isolectin-I (Sigma-Aldrich Co., St Louis, MO, USA) followed by tyramide signal amplification enhancement (PerkinElmer Inc., Waltham, MA, USA). Capillaries were visualized by $3,3^{\prime}$-diaminobenzidine tetrahydrochloride, counted and expressed as the number of capillaries per $\mathrm{mm}^{2}$. In order to quantify the total collagen content in the heart tissues, measurement of pro-collagen $1 \alpha 1$ (an established biomarker of cardiac fibrosis) was performed using the Mouse Pro-Collagen I alpha 1 CatchPoint SimpleStep ELISA Kit from Abcam (ab229425). Tissues were homogenized, after protein quantification (Bradford assay) $100 \mu \mathrm{g}$ of proteins were assayed according to manufacturer's instruction. Fluorescence were measured at 530/590 using a 96-well plate reader Tecan Infinite M200 plate-reader (Tecan Life Sciences Home, Männedorf, Switzerland).

\section{Cardiac apoptosis through TUNEL and caspase-3 assay and MMP-9 expression}

Cardiac sections measuring $6 \mu \mathrm{m}$ were examined for the presence of apoptotic cardiomyocytes by TdT-mediated dUTP nick-end labelling (TUNEL) assay using a Promega Dead End ${ }^{\mathrm{TM}}$ colorimetric TUNEL system (Promega, Madison, WI, USA) with a streptavidin-peroxidase system. Controls were obtained by omitting the TdT enzyme from the reaction mixture. The percentage of TUNELpositive myocytes was determined by counting 10 random fields per section under a microscope (Nikon NIS Elements). Using this procedure, apoptotic nuclei were stained dark brown. Labelled nuclei were counted and expressed as the percentage of positively stained cells. The Caspase- 3 activity in heart tissue was measured using a Caspase- 3 colorimetric assay kit (Clontech, USA) according to the manufacturer's instructions (results were reported as ng of Caspase-3/g of tissue). MMP-9 were associated with collagen maturation in heart failure, demonstrating the important role of these enzymes in fibrosis through collagen configuration, activation, and deposition. Therefore, we quantified MMP-9 in heart tissues through Mouse MMP9 ELISA Kit (ab253227, AbCam, Milan, Italy) following the manufacturer's instructions; results are expressed as pg of MMP-9/mg of protein (determined through Bradford assay).

\section{SGLT-2 expression through western blot analysis}

Same studies indicated that human and murine cardiomyocytes express SGLT-2 [32], although other studies indicate its absence [33]. To confirm this data, we analysed SGLT-2 expression in heart and renal (as positive control) tissues of mice. For preparation of Protein Lysates from Mouse Tissues and western blot analysis, frozen mouse kidney and heart tissues $(50 \mathrm{mg})$ were cut on dry ice and resuspended in $1 \mathrm{~mL}$ of RIPA buffer (Tris- $\mathrm{HCl}$ pH 8.0, 50 mM sodium chloride, 1.0\% NP-40, $0.5 \%$ sodium deoxycholate, $0.1 \%$ sodium dodecyl sulfate, protease inhibitors). Tissues were homogenized and transferred to a new tube. Later they were centrifuged at $13,000 \mathrm{rpm}$ at $4{ }^{\circ} \mathrm{C}$ for $20 \mathrm{~min}$ and the supernatants were collected. The protein concentrations were determined by colorimetric assay (Biorad, Italy). The tissues extracts were diluted 1:1 in sample buffer $2 \mathrm{X}$ Laemli $(0.217 \mathrm{M}$ Tris- $\mathrm{HCl} \mathrm{pH}$ 8.0, SDS 52.17\%, 17.4\% glycerol, 0,026\% bromophenol blue, $8.7 \% \beta$-mercaptoethanol), and then were boiled for $3 \mathrm{~min}$. Equal amounts of protein $(50 \mu \mathrm{g})$ were run and separated by SDS-PAGE gel. Primary antibody used was: SGLT-2 (Thermo Fisher Scientific), while GAPDH (Cell Signaling) antibody was used as loading control.

\section{RNA isolation and RT-PCR}

Mice heart and kidney tissues (50 mg each) were submerged in RNA stabilizing solution (RNAlater $\left.{ }^{\circledR}\right)$. Samples were then minced and RNA were isolated using TRIzol Reagent (Invitrogen-Life Technologies) according to the manufacturer's protocol and subsequently reverse transcribed through Super Script VILO kit (Invitrogen). Relative mRNA levels were performed by qRT-PCR using iQ SYBR ${ }^{\circledR}$ Green Supermix (Bio-Rad Laboratories). 
Specific mouse primers used for qRT-PCR were: SGLT-2 Fw: 5'- TAGTTGGAAGGCTCTGGGTG-3'; SGLT-2 Rev: 5' - CCCAACTAGTCCCCAGAAGG-3'. Data were normalized with GAPDH Fw: 5'- CCCCAATGTGTC CGTCGTG-3'; GAPDH Rev: 5'- GCCTGCTTCACC ACCTTCT- $3^{\prime}$ by using $\Delta \Delta C T$ method. Results were expressed as fold-change compared to the control.

\section{Statistical analysis}

Continuous data were expressed as mean \pm SD. Nonparametric tests were used both for paired and unpaired comparisons. Repeated measures ANOVA was used for all baseline to end-of-study comparisons. A p value $<0.05$ was considered significant.

\section{Results}

\section{Cell viability and calcium homeostasis}

Incubation with DOXO decreased the viability of cardiomyocytes in a concentration-dependent manner, with an $\mathrm{IC}_{50}$ below $10 \mu \mathrm{M}$, whereas DOXO and EMPA coincubation increased cell viability (Fig. 1A). For example, the viability of cardiomyocytes exposed to DOXO at $50 \mu \mathrm{M}$ plus EMPA at 10,50 or $500 \mathrm{nM}$ was $21.8 \%, 53.1 \%$ and $71 \%$, respectively, higher than that of cardiomyocytes exposed to DOXO alone. In addition, cell viability was $18.8 \%$ higher in cardiomyocytes treated with EMPA alone at $500 \mathrm{nM}$ than in control cells (Fig. 1B). Moreover, $\left[\mathrm{Ca}^{2+}\right] \mathrm{i}$ (intracellular calcium) production was significantly higher in cardiomyocytes treated with DOXO and lipopolysaccharides (LPS) than in untreated cells $(\mathrm{p}<0.001$ for both) (Fig. 1C). At $24 \mathrm{~h}$ of incubation, the mean $\left[\mathrm{Ca}^{2+}\right] \mathrm{i}$ of cardiomyocytes incubated with DOXO and EMPA at 10, 50 and $500 \mathrm{nM}$, was about $8 \%, 40 \%$ and $53 \%$ lower than the mean $\left[\mathrm{Ca}^{2+}\right] \mathrm{i}$ in cells treated with DOXO alone $(\mathrm{P}<0.001)$ (Fig. $1 \mathrm{C})$. The same results were obtained under pro-inflammatory conditions in LPS- and LPS/EMPA-treated cells (Fig. 1C). As control, we evaluated the effects of EMPA on the anticancer efficacy of DOXO in human estrogen-responsive (Fig. 1D) and triple negative breast cancer cells (Fig. 1E); in line with literature [34], EMPA did not affects the anticancer effects of DOXO in breast cancer cells, indeed, at some concentrations it seems to increase slightly the cytotoxicity of DOXO. These preliminary results, although already confirmed by recent research [34], are of great interest and will be the performed by our group in further in-depth studies.

\section{Intracellular reactive oxygen species (iROS), nitric oxide and lipid peroxidation}

Exposure to LPS or DOXO alone increased the iROS content of 2.1- and 2.6-fold, respectively, compared to untreated cells (Fig. 2A). Levels of iROS were 12\%,
$33.8 \%$ and $62.5 \%$ lower in cells treated with EMPA/ DOXO than DOXO alone $(\mathrm{P}<0.001$ for all). Notably, the anti-oxidant effects of EMPA at $50 \mathrm{nM}$ were comparable to those of gallic acid, which is a common bioactive anti-oxidant compound (Fig. 2A). EMPA significantly decreased the production of the lipid peroxidation markers MDA and 4-HNA in cardiomyocytes under pro-inflammatory conditions (Fig. 2B). Lipid peroxidation was two-fold higher in cardiomyocytes treated with DOXO than in untreated cardiomyocytes $(\mathrm{p}<0.001)$. DOXO and EMPA at 10, 50 and $500 \mathrm{nM}$ decreased the production of MDA and 4-HNA by $14 \%$ and $11 \%$ ( $p<0.001$ for both), $24 \%$ and $26 \%$ ( $<<0.001$ for both), $49 \%$ and $35 \%(\mathrm{p}<0.001$ for both), respectively, compared to cells treated with DOXO alone (Fig. 2B). Combination treatment of EMPA/DOXO reduced significantly the nitric oxide production (involved in pathogenesis of cardiovascular diseases $[35,36]$ compared to cells exposed to DOXO (Fig. 2C).

\section{Quantification of cytokines}

Interleukin-8 was 2.5-fold higher in cardiomyocytes exposed to DOXO than in untreated cells (Fig. 3A). Treatment with EMPA at 10, 50 and $500 \mathrm{nM}$ resulted in a decrease of interleukin 8 of $8.8 \%(\mathrm{p}<0.05), 24 \%$ $(\mathrm{p}<0.001)$ and $43 \%(\mathrm{p}<0.001)$ versus DOXO alone. Interleukin- 6 , one of the most studied cytokine involved in cardiovascular diseases and cancer progression [37, 38], decreased significantly in cells exposed to EMPA/DOXO (12.4\%, $21 \%$ and $49.5 \%$, at 10,50 and $500 \mathrm{nM}$, respectively, $\mathrm{p}<0.001$ for all), compared to cardiomyocytes exposed to DOXO alone (Fig. 3B). Moreover, as shown in Fig. $6 \mathrm{C}$, EMPA at 10,50 and $500 \mathrm{nM}$ reduced the production of interleukin $1-\beta$ by $13 \%, 26 \%$ and $48 \%$, respectively $(\mathrm{p}<0.001)$ compared to cells treated with DOXO alone (Fig. 3C).

\section{Leukotriene B4 assay}

Leukotrienes B4 production was 3.4 times higher in cells treated with arachidonic acid than in untreated cells $(125.3 \pm 5.7 \mathrm{pg} / \mathrm{ml}$ vs $36.4 \pm 6.7 \mathrm{pg} / \mathrm{ml}$; p < 0.001) (Fig. 3, D). Pre-treatment with EMPA at 10, 50 and $500 \mathrm{nM}$ reduced the production of leukotrienes by $7 \%$ (not significant), $16 \%(\mathrm{p}<0.05)$ and $33 \%(\mathrm{p}<0.001)$ versus cells exposed to arachidonic acid alone (Fig. 3D). Leukotrienes B4 production was 4.3 times higher in cells treated with DOXO than in untreated cells $(\mathrm{p}<0.001)$. Notably, leukotriene B4 production was 24\%, 33\% and 50\% lower in cardiomyocytes treated with DOXO and EMPA at 10, 50 and $500 \mathrm{nM}$, respectively than in cells exposed to DOXO alone. 

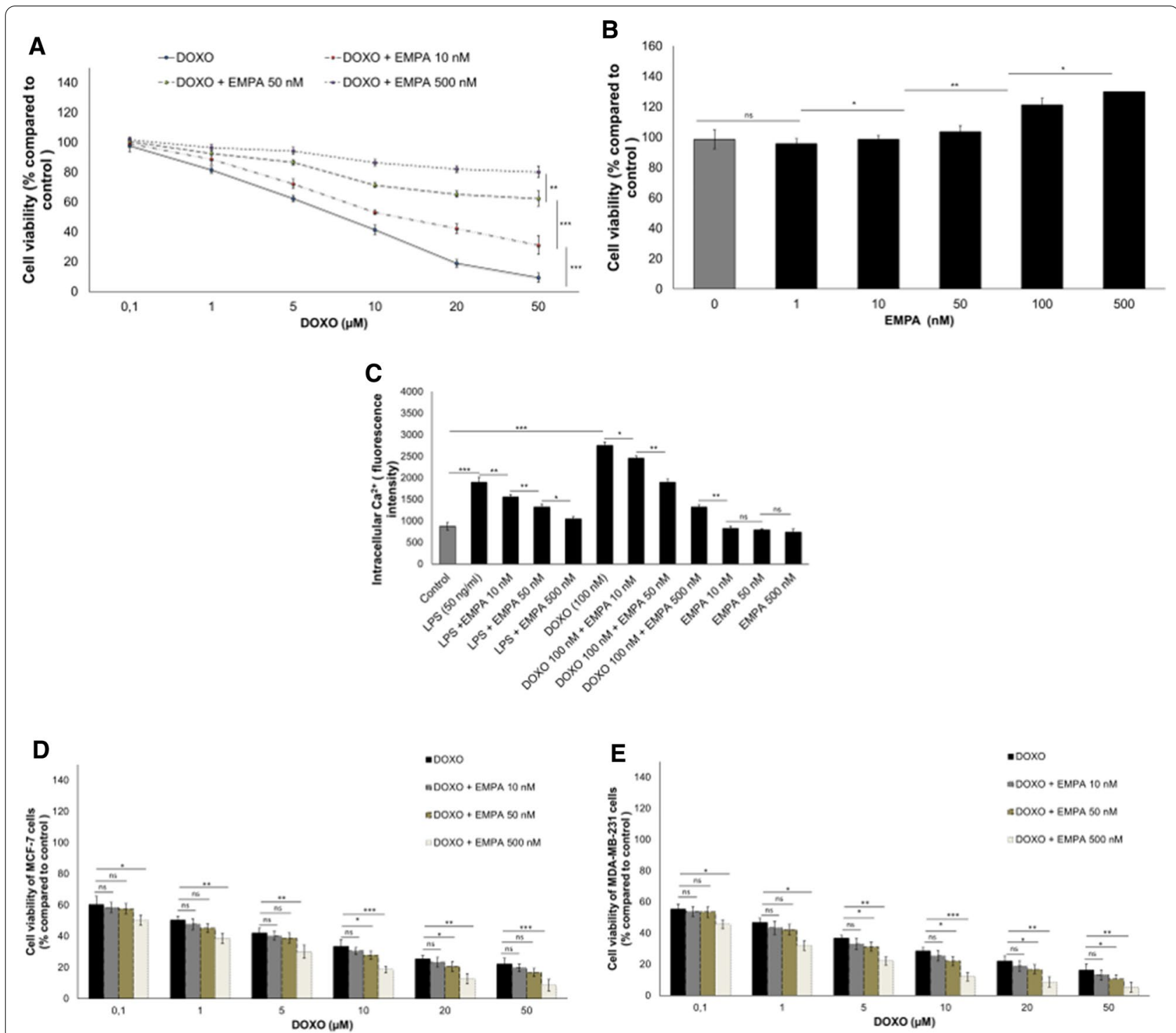

Fig. 1 EMPA exerts a cytoprotective effect on cardiomyocytes exposed to doxorubicin (DOXO) through the reduction of intracellular Ca2 ${ }^{+}$overload in a concentration-dependent manner. $10 \times 10^{3} \mathrm{HL}-1$ cells/well were seeded in 96-well plate and were cultured under different conditions. $\mathbf{A}$ cell viability of cardiomyocytes treated with DOXO (from 0.1 to $50 \mu \mathrm{M}$ ), alone or combined with EMPA (EMPA) (10,50 or $500 \mathrm{nM})(\mathrm{n}=6$ for each concentration. One-way ANOVA analysis). B Cardiomyocyte viability under exposure to EMPA from 1 to $500 \mathrm{nM}$. ( $\mathrm{n}=6$ for each concentration. One-way ANOVA analysis). C For quantification of intracellular calcium $\left(\mathrm{Ca} 2^{+}\right), 5 \times 10^{3}$ cells/well were seeded in a 24-well plate and allowed to grow for $24 \mathrm{~h}$; after, cardiomyocytes were not exposed (control) or exposed to EMPA (10, 50, $500 \mathrm{nM}$ ), lipopolysaccharides (LPS) (50 ng/ml) or DOXO $(100 \mathrm{nM})$ alone or with EMPA at 10, 50 and $500 \mathrm{nM}$. ( $\mathrm{n}=3$ for each group). One-way ANOVA analysis). Values are expressed $\pm S D$. ${ }^{* * * P}<0.001$; ${ }^{*} \mathrm{P}<0.01 ; * \mathrm{P}<0.05 ;$ ns: not significant

\section{p65/NF-kB assay}

EMPA decreased the NF- $\mathrm{kB}$ activation in a dose-dependent manner in cardiomyocytes compared to untreated cells (Fig. 3E). Treatment with EMPA at 10, 50 and $500 \mathrm{nM}$ decreased NF- $\mathrm{KB}$ activation by $16 \%(\mathrm{p}<0.05)$, $32 \%(\mathrm{p}<0.05)$ and $53 \%(\mathrm{p}<0.001)$ versus cells exposed to DOXO. The same effects of EMPA were recently described by Andreadou I et al. [39].

\section{MyD88 and NLRP3 expression}

The MyD88 complex, also called myddosome and NLRP3 are analysed in cardiac cells exposed to DOXO and EMPA; as shown in Fig. 3F, DOXO strongly increased both pro-inflammatory markers $(\mathrm{p}<0.01$ for both), in agree with other preclinical studies. Treatment with EMPA decreases significantly MyD88 and NLRP3 indicating their involvement in cardiovascular 

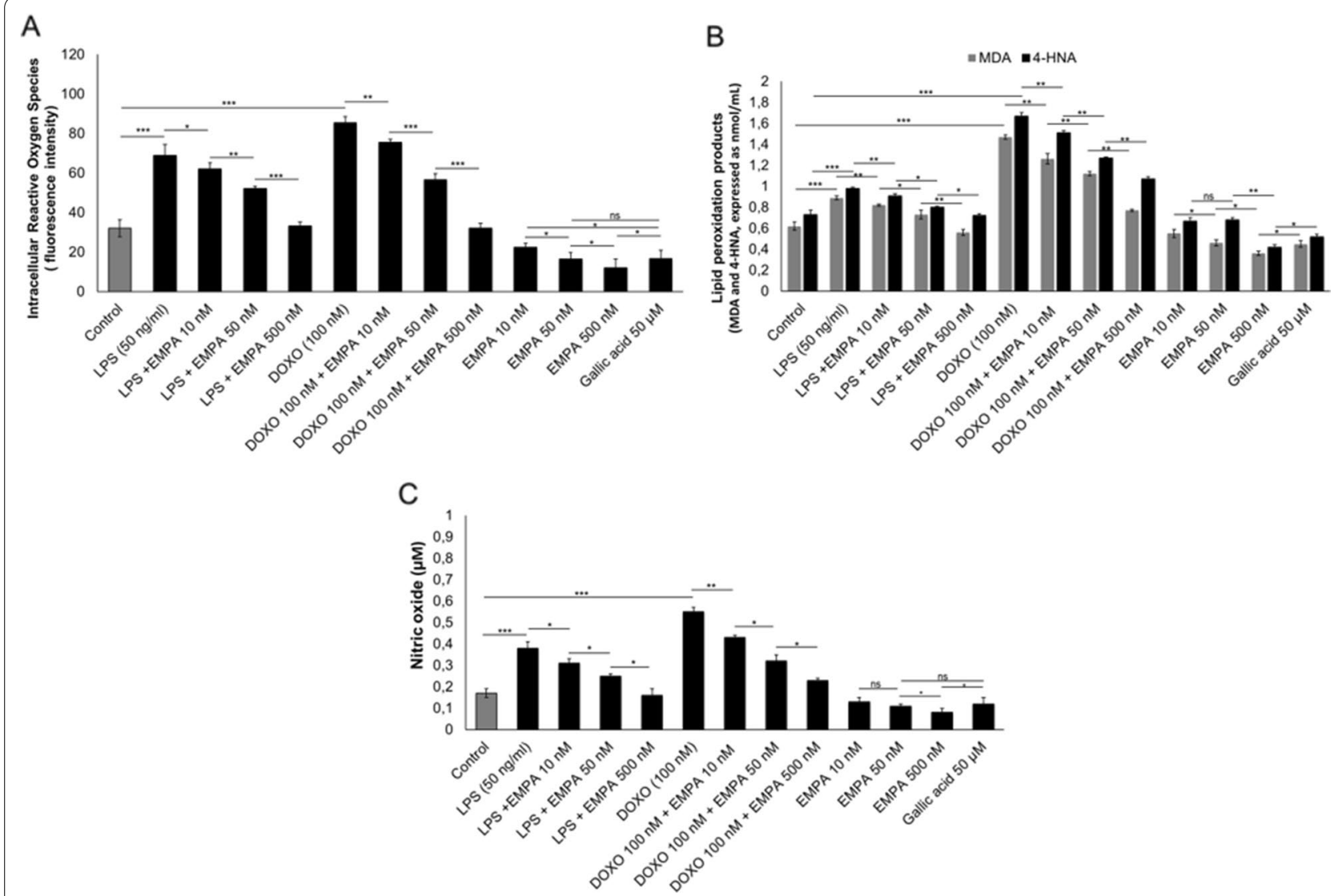

Fig. 2 EMPA has anti-oxidant effects on cardiomyocytes under pro-inflammatory conditions (LPS) and under exposure to doxorubicin (DOXO). A Intracellular reactive oxygen species (iROS) quantification (expressed as cell fluorescence); $(n=3)$ B Quantification of lipid peroxidation products $(4-\mathrm{HNA}$ and MDA) (expressed in $\mathrm{nmol} / \mathrm{mL})(\mathrm{n}=3)$; C Production of nitric oxide $(\mu \mathrm{M})(\mathrm{n}=3)$. Experiments were performed in cardiomyocytes $\left(5 \times 10^{3}\right.$ cells/well seeded in a 24-well plate) untreated (control) or treated with gallic acid (as positive antioxidant control), EMPA (10,50, 500 nM), LPS $(40 \mathrm{ng} / \mathrm{ml})$ or DOXO (100 nM) alone or co-incubated with EMPA at 10,50 and $500 \mathrm{nM}$. One-way ANOVA. Values are expressed $\pm S D$. ${ }^{* * *} \mathrm{P}<0.001$; ${ }^{*} \mathrm{P}<0.01$; ${ }^{*} \mathrm{P}<0.05$; ns: not significant

beneficial effects of SGLT2 inhibitor during DOXO therapy.

\section{Confocal scanning laser microscope imaging}

Cellular imaging confirms the anti-inflammatory effects of EMPA. Cardiomyocytes exposed to DOXO increased significantly the p65/NF-kB expression (Fig. 3C) and nuclear localization compared to untreated cells (Fig. 3A); notably, exposure to EMPA only (Fig. 3B) and combined to DOXO (Fig. 3D) decreased significantly the staining of p65/NF-kB in both in nuclear and cytosol of the cells, indicating anti-inflammatory effects.

\section{Preclinical studies \\ Glycemia}

Before treatments, the mean blood glucose was $196.4 \pm 43 \mathrm{mg} / \mathrm{dl}$. After treatments with EMPA, the mean blood glucose was $204.6 \pm 56 \mathrm{mg} / \mathrm{dl}$ and no significant difference were seen between the groups at the end of treatment $(\mathrm{p}>0.05)$. These results are in line with other studies [32] confirming the non-relevant effects of EMPA in non-diabetic mice.

\section{Effects on ferroptosis, xanthine oxidase} and pro-inflammatory biomarkers

Increasing evidence indicates that ferroptosis plays a critical role in doxorubicin-induced cardiotoxicity; in agree with literature, DOXO increased MitoPeDPP, a marker of mitochondrial lipid peroxidation involved in ferroptosis (Fig. 4A) and MDA content in cytosolic (Fig. 4B) and mitochondrial (Fig. 4C) fractions of cardiac tissues. Treatment with EMPA during exposure to DOXO reduced significantly ferroptosis and MDA content in the heart, especially in the cardiac mitochondrial fraction $(5.6 \pm 2.6$ vs $15.2 \pm 3.3$ for DOXO group; $\mathrm{p}<0.001)$. The recent study by Tanaka et al. [31] showed that the increased oxidative stress induced by tissue xanthine oxidase activation is deeply involved in doxorubicin-induced 

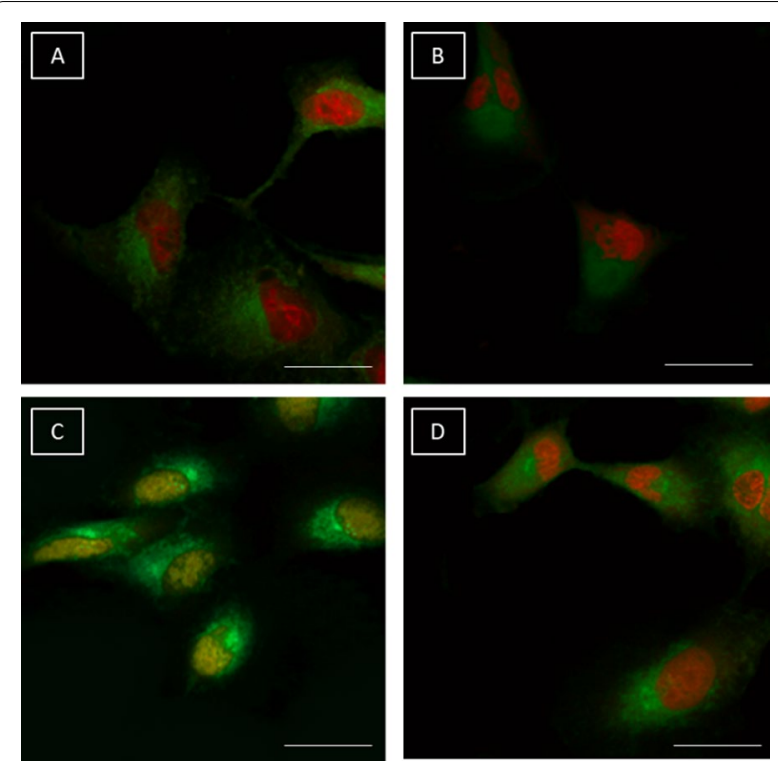

Fig. 3 Co-incubation of EMPA (EMPA) and doxorubicin (DOXO) reduced the expression of pro-inflammatory interleukins, leukotrienes and p65/NF-Kb compared to only DOXO-treated cells. For each experiment, $5 \times 10^{3}$ cells/well were seeded in a 96-well plate; cells were exposed to EMPA $(10,50,500 \mathrm{nM})$, LPS $(40 \mathrm{ng} / \mathrm{ml})$, DOXO $(100 \mathrm{nM})$ alone or with EMPA at 10, 50 and $500 \mathrm{nM}(\mathrm{n}=4$ /group). Expression of (A) Interleukin-8, (B) Interleukin-6 and (C) Interleukin1- $\beta$ ( $\mathrm{pg} / \mathrm{mL})$. D Leukotriene B4 expression $(\mathrm{pg} / \mathrm{mL})$ in cardiomyocytes exposed to arachidonic acid $(10 \mu \mathrm{M})$, EMPA $(10,50,500 \mathrm{nM})$ alone or associated to arachidonic acid, DOXO (100 nM) alone or co-incubated with EMPA at 10, 50 and 500 nM. E p65/NF-kB DNA binding activity, expressed as fold of untreated (control) cells $(n=3)$. (F) MyD88 and NLRP3 expression (fold of control), $(n=3)$; One-way ANOVA. Value are expressed $\pm S D$. ${ }^{* *} P<0.001 ;{ }^{* * P}<0.01 ;{ }^{*} P<0.05$; ns: not significant. G: Confocal laser scanning microscope images of cardiomyocytes exposed to medium alone (A), EMPA $100 \mathrm{nM}$ (B), DOXO $100 \mathrm{nM}$ (C) and EMPA (100 nM) DOXO (100 nM) in combination (D) for $24 \mathrm{~h}$ ( $n=3 /$ group). Green fluorescence indicates p65/NF-kB staining; red fluorescence indicates cell nucleus. Scale bar: $50 \mu \mathrm{M}$

cardiotoxicity; as expected, DOXO increased the expression of xanthine oxidase compared to control $(18.5 \pm 1.8$ vs $2.1 \pm 1.2 \mathrm{mU} / \mathrm{mg}$ of protein; $\mathrm{p}<0.001$ ) (Fig. $4 \mathrm{D}$ ); in EMPA-DOXO group (Fig. 4E) xanthine oxidase is significantly reduced $(7.3 \pm 2.5 \mathrm{vs} 18.5 \pm 1.8 \mathrm{mU} / \mathrm{mg}$ of protein; $\mathrm{p}<0.001)$. As expected, IL-8, 6 and $1-\beta$ expression was significantly higher in the heart, liver and kidney of mice treated with DOXO compared to untreated mice $(\mathrm{p}<0.005$ for all) (Fig. 4E). Cytokines were significantly lower in EMPA-treated mice than in DOXO-treated mice ( $p<0.001$ for all). Specifically, IL-1 $\beta$, IL- 6 and IL- 8 cardiac expression were $51 \%, 52 \%$ and $54.2 \%$ lower, respectively, in EMPA-treated mice than in DOXO-treated mice. In liver, the expression of IL- $1 \beta$, IL- 6 and IL- 8 was $45 \%, 56 \%$ and $48 \%$, respectively lower in mice treated with DOXO alone than in mice treated with DOXO plus EMPA. Similar findings were obtained in kidney tissue extract, i.e., IL-1 1 , IL-6 and IL-8 expression was $29.5 \%, 41 \%$ and $47 \%$ lower in mice treated with DOXO plus EMPA than in mice treated with DOXO alone (Fig. 4E). Considering that the NLRP3 and MyD88 are key activators of cytokine storm involved in heart failure, we evaluated their expression in cardiac tissue (Fig. 4F). MyD88 and NLRP3 expression ( $\mathrm{pg} / \mathrm{mg}$ of protein) were significantly reduced by $35-40 \%(\mathrm{p}<0.001)$ compared to DOXO group, indicating anti-inflammatory effects (Fig. 4F).

\section{Effects on fibrosis and apoptosis and SGLT2 expression}

Expression of cardiac collagen (imaged in red in the histological pictures) (Fig. 5A, B) was significantly higher DOXO group compared to untreated mice. Treatment with EMPA during exposure to DOXO reduced its expression. Quantitative data confirms that pro-collagen $1 \alpha 1$ expression in EMPA-DOXO group was significantly reduced compared to DOXO (6.7 \pm 1.2 vs $16.3 \pm 1.7 \mathrm{ng} /$ mg of total protein; $\mathrm{p}<0.001$ ) (Fig. 5C). MMP-9 expression, another biomarker of cardiac fibrosis and heart failure, was also reduced in EMPA-DOXO group compared to DOXO $(547.3 \pm 111$ vs $899.6 \pm 106 \mathrm{pg} / \mathrm{mg}$ of total protein; $\mathrm{p}<0.001$ ) (Fig. 5D). Apoptotic nuclei in cardiac tissue (imaged as green signals in Fig. $5 \mathrm{E}$ and quantified in Fig. 5F) were 15.8-fold more numerous in DOXOtreated than in untreated mice, and the number of apoptotic events was 35\% lower in EMPA-treated mice than in DOXO-treated mice $(\mathrm{p}<0.001)$. Caspase-3 expression in cardiac tissues was also reduced in EMPA-DOXO group compared to DOXO $(1.5 \pm 0.28$ vs $2.9 \pm 0.24 \mathrm{ng} / \mathrm{g}$ of tissue; $\mathrm{p}<0.001$ ) (Fig. 5G) indicating anti-apoptotic

\footnotetext{
(See figure on next page.)

Fig. 4 A EMPA reduced significantly the DOXO -induced ferroptosis in cardiac tissues, determined by Mitochondrial lipid peroxidation, measured using MitoPeDPP (ratio to sham). EMPA reduced significantly the DOXO -induced MDA content in cytosolic (B) and mitochondrial fraction (C) of cardiac tissues (ratio to sham). D EMPA reduced significantly the xanthine oxidase content in cardiac tissues during treatment with DOXO (mU/mg of protein). E EMPA exerts anti-inflammatory effects on the liver, heart and kidney of mice treated with DOXO. F EMPA reduces pro-inflammatory markers MyD88 and NLRP3 in cardiac tissue during DOXO treatments. For both, we quantified the expression of interleukin 1- $\beta$, interleukin 6 and interleukin 8 (pg/mg of protein) in heart, liver and left kidney lysates of mice untreated (Sham) or treated with EMPA, DOXO or DOXO/EMPA for 7 days ( $n=6$ for each group); in heart tissues only, we quantified the expression of MyD88 and NLRP3 through mouse ELISA kits (pg of marker/mg of protein). One-way ANOVA. Values are expressed $\pm S D$. ${ }^{* *} P<0.001$; ${ }^{* * P}<0.01$; ${ }^{*} P<0.05$; ns: not significant
} 

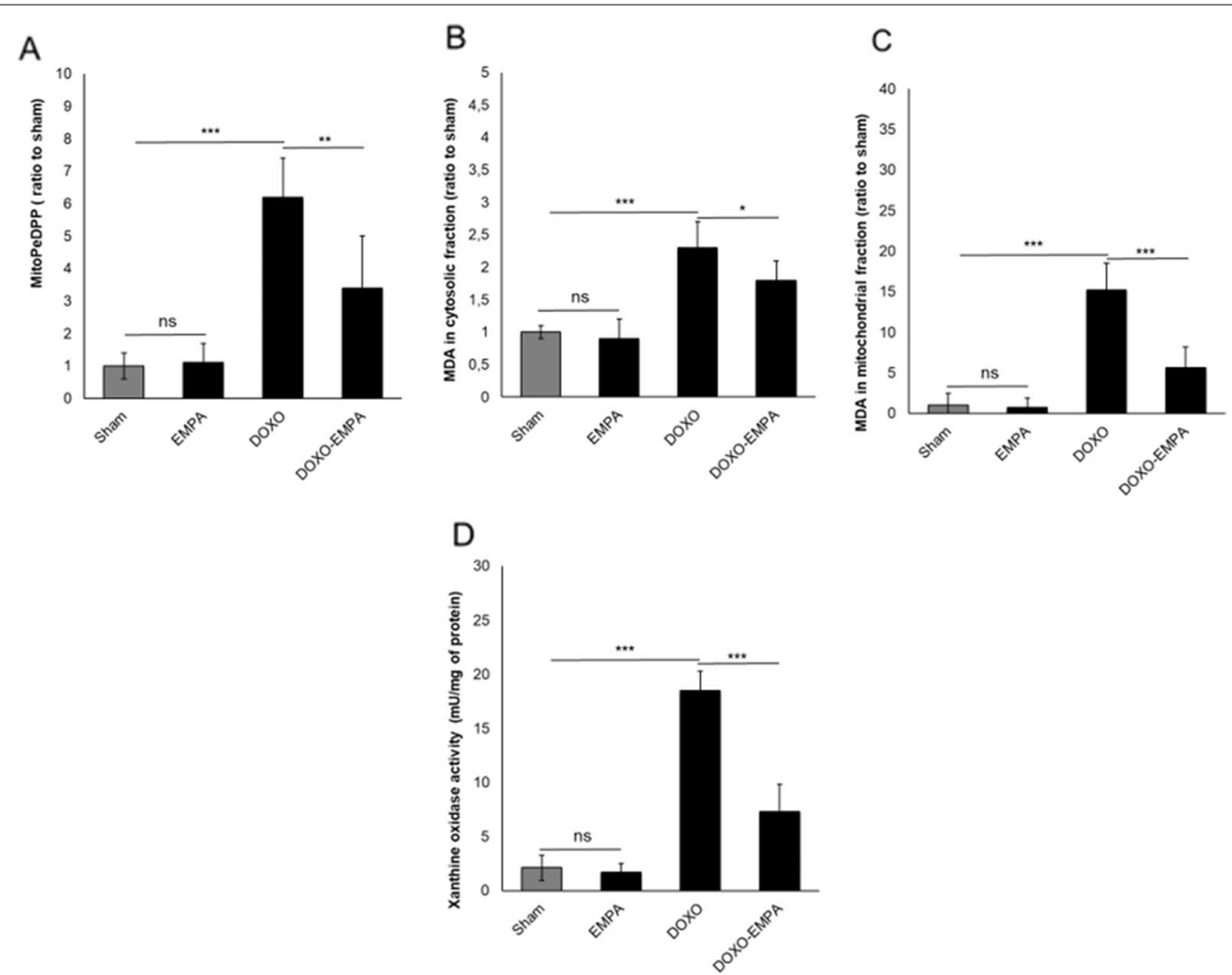

E

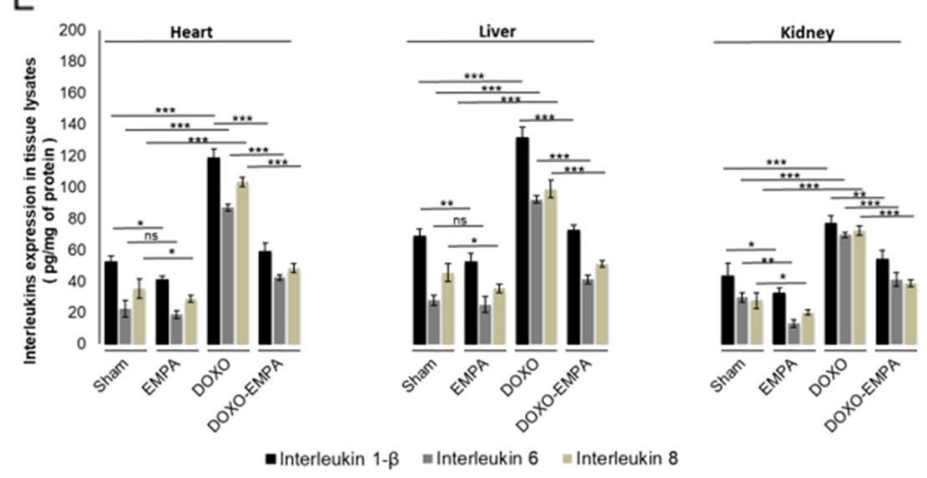

F

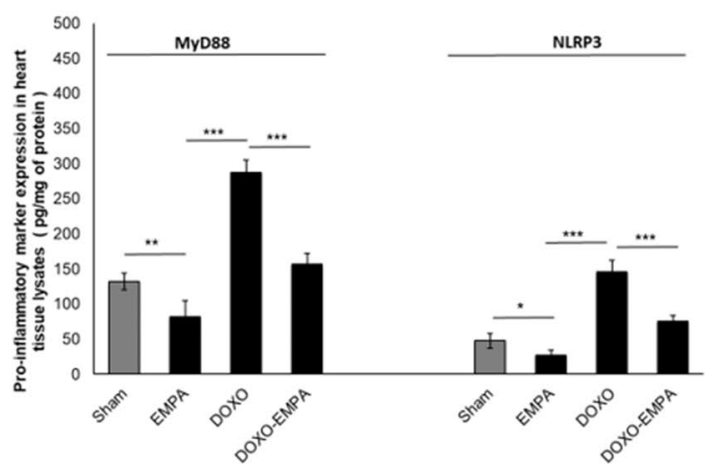

Fig. 4 (See legend on previous page.) 
effects of EMPA in preclinical models. Notably, western blot analysis (Fig. 5H) showed a very high expression of SGLT-2 in kidney and confirm its expression in cardiac tissue, in line with other studies [32]. RT-PCR confirmed detectable levels of the SGLT-2 mRNA in cardiac tissues (Fig. 5I).

\section{Effects on cardiac functions}

No significant differences were observed for IVS; dD, LVID;d-D, LVPW;d-D, LV Mass, LV Vol; d, LV Vol;s between the experimental groups (Fig. 6). On the other hand, treatment with doxorubicin was associated with a significant increase in LVID; s-D and reduction in EF ( $-10.3 \%$ compared to baseline: $\mathrm{p}<0.05)$ and FS $(-19.8 \%$ compared to baseline; $\mathrm{p}<0.05$ ). EMPA-DOXO mice had a significant improvement in EF $(88.3 \pm 2.3$ vs $81.2 \pm 2.5$ (\%); $\mathrm{p}<0.05)$ and FS $(58.7 \pm 3.5$ vs $48.8 \pm 2.9(\%) ; \mathrm{p}<0.05)$ compared to DOXO group (Fig. 6).

Particular attention was made on the evaluation of cardiac strain on long-axis images and ventricular functions (studied by myocardial deformation along the radial and longitudinal axes) as useful echocardiographic markers of cardiotoxicity [40-43]. Strain analysis showed that EMPA significantly improves cardiac functions when used in combination with DOXO compared to DOXO treated mice (quantitative data in Fig. 7A; imaging analysis in Fig. 7B). Radial strain (RS) is $30.3 \%$ in EMPA-DOXO vs $15.7 \%$ in DOXO groups $(\mathrm{P}<0.001)$; longitudinal strain $(\mathrm{LS})$ is - $17 \%$ in EMPA-DOXO vs $-11.7 \%$ in DOXO groups $(\mathrm{P}<0.001)$ (Fig. 7A). Moreover, the association of EMPA and DOXO brings strain levels similar to those of untreated mice (control) (Fig. 7A), clearly indicating a cardioprotective effect of EMPA in DOXOinduced cardiotoxicity.

\section{Discussion}

In patients with type 2 diabetes and established cardiovascular disease, EMPA reduced the risk of cardiovascular death and heart failure hospitalizations in the EMPA-REG OUTCOME ${ }^{\circledR}$ trial $[8,9]$. More recently, EMPA reduced heart failure hospitalizations and cardiovascular mortality in both high and low risk patients thereby confirming its robust and significant cardioprotective effects [44].

DOXO-induced cardiotoxicity is induced by several mechanisms mediated by increased levels of iROS and $\left[\mathrm{Ca}^{2+}\right] \mathrm{i}$ in cardiomyocytes associated to a proinflammatory cytokine storm leading to apoptosis, necrosis and mitochondrial dysfunctions. Moreover, treatment with doxorubicin leading to a systemic and local inflammation in cancer patients, partially due to cytosolic damages several organs like liver and heart; doxorubicin exposure in liver increased the production of circulating IL-1- $\beta$, IL- 6 and hs-CRP (hypersensitive-C-reactive-protein) leading to increased risk of cardiovascular and metabolic diseases [45]. Other preclinical and clinical studies evidenced direct damages induced by doxorubicin, partially mediated by reduced AMPK expression and induction of doublestrand breaks and cell death by intercalating into DNA and blocking the activity of the topoisomerase II (TOP2) enzymes called TOP2 $\beta$ and TOP $2 \alpha$ [46]. Therefore, consolidated that EMPA exerts systemic and cardiac anti-inflammatory effects in preclinical and clinical trials, its use during treatment with doxorubicin is a promising cardioprotective strategy.

A recent preclinical study suggests that EMPA could reduce intracellular $\mathrm{Ca}^{2+}$ under high glucose [47]. It is feasible that EMPA exerts this effect by inhibiting the $\mathrm{Na}^{+} / \mathrm{H}^{+}$exchanger, thereby leading to a lower concentration of intracellular $\mathrm{Ca}^{2+}$ in cardiomyocytes $[48,49]$. Given that DOXO exerts cardiotoxic effects by increasing intracellular $\mathrm{Ca}^{2+}$ concentration $[12,49]$ it is feasible that the improvement of calcium homeostasis contributes to the cardioprotective effects of EMPA and cardiomyocyte contractility.

Recent preclinical and clinical studies demonstrated that oxidative stress is one of the most important events implicated in the cardiotoxicity of anticancer drugs [50]. Interestingly, EMPA exerts antioxidant effects in cardiomyocytes thereby reducing lipid peroxidation during incubation with DOXO [51-53]. Notably, NO is over-produced in

\footnotetext{
(See figure on next page.)

Fig. 5 Cardiac fibrosis and apoptosis in mice treated with saline solution (Sham), EMPA $10 \mathrm{mg} / \mathrm{kg} /$ day, DOXO $2.17 \mathrm{mg} / \mathrm{kg} /$ day or EMPA associated to DOXO ( $n=6$ for each group). A representative images of the interstitial fibrosis (collagen content, indicative of the fibrosis) in cardiac tissue. B cardiac collagen quantification (\% of collagen of area) in heart tissue. C Heart pro-collagen 1-a1 quantification in cardiac tissue ( $\mathrm{ng} / \mathrm{mg}$ of total protein); D MMP-9 content ( pg/mg of protein) in cardiac tissue, indicative of fibrosis. E apoptosis imaging in cardiac tissue ( in green, apoptotic nuclei). $\mathbf{F}$ apoptotic nuclei, expressed as relative percentage of positive nuclei in heart tissue (two-way ANOVA with a Bonferroni post hoc test). $\mathbf{G}$ Caspase-3 expression in cardiac tissue (expressed as ng of Caspase-3/g of tissue). H SGLT-2 protein expression in cardiac and renal tissues of C57B/6 mice through western blot analysis. I Real Time -PCR analysis indicating the relative mRNA expression of SGLT-2 in cardiac and renal tissues of C57B/6 mice. Values are expressed \pm SD. ${ }^{* *} \mathrm{P}<0.001 ;{ }^{* *} \mathrm{P}<0.01 ;{ }^{*} \mathrm{P}<0.05$; ns: not significant
} 


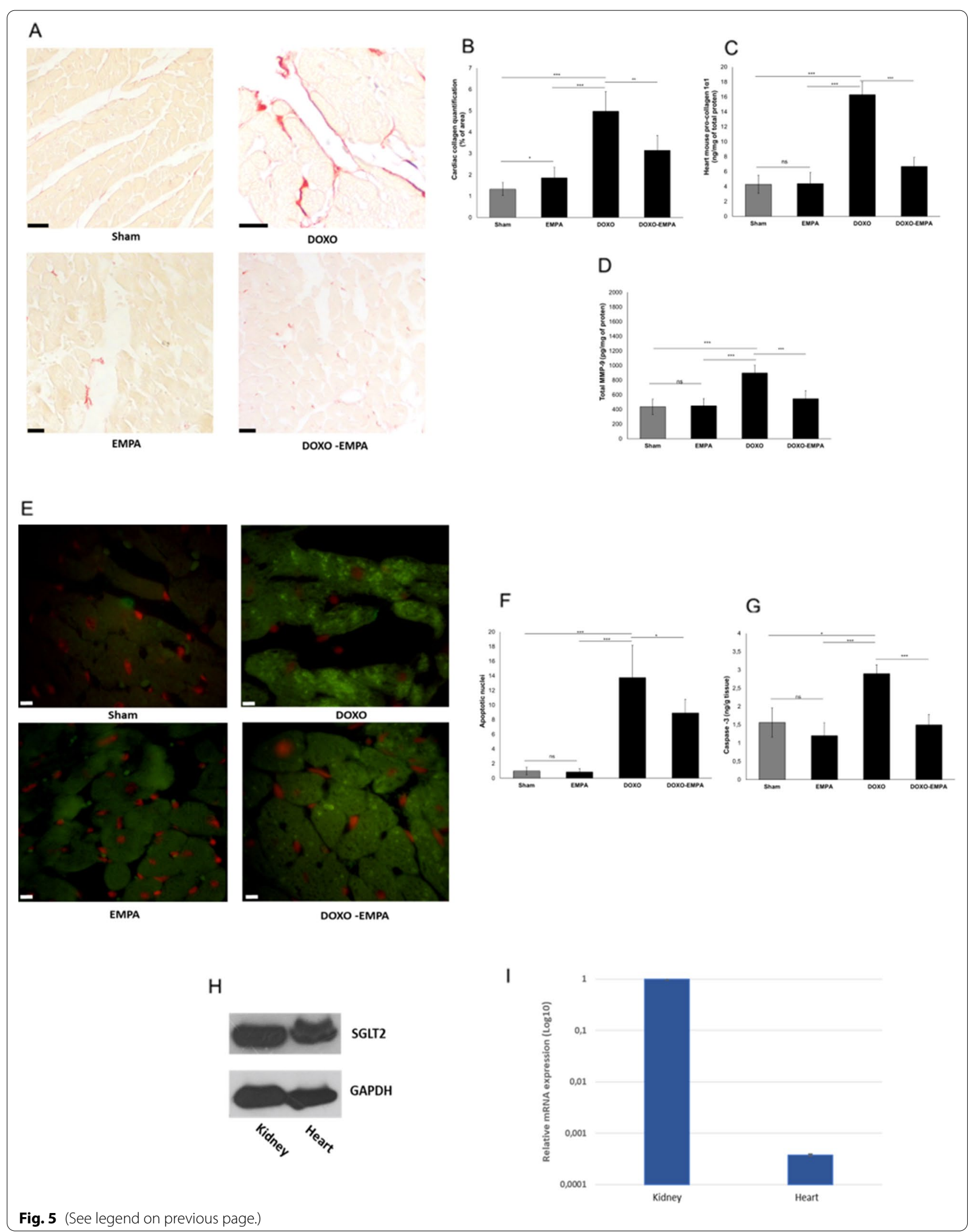


anthracycline-treated patients [54] thereby increasing the risk of cardiac failure and cardiomyopathy [55]. Our finding that EMPA reduces NO production in cells exposed to DOXO lays the preliminary foundation for preclinical studies of NO homeostasis in cancer patients.

The pro-inflammatory heart microenvironment is a key driving force of the cardiotoxicity seen in cancer patients [56-58]. The pharmacological inhibition of IL-1 improves the left ventricle ejection fraction and fraction shortening in preclinical models during DOXO exposure [59]. Interleukins 8 and 6 are also associated to cardiovascular disease, heart failure and stroke [60]. Here, EMPA improved cardiac, hepatic and renal microenvironment through the reduction of pro-inflammatory cytokines during treatment with DOXO. As summarized in Fig. 8, EMPA inhibits activity of SGLT-2 thereby reducing intracellular glucose and sodium in cardiomyocytes, consequently increasing 5' AMP-activated protein kinase (AMPK) that has a key role in doxorubicin-mediated cardiomyocyte injury through SMAD, NoX and Wnt [61]. The overall picture of the study is in line with other recent work highlighting on the protective effects of SGLT2 inhibitors on DOXO induced cardiotoxicity [62, 63]. Interestingly, EMPA exerts cardiorenal benefits that, at least in part, are mediated by the activation of SIRT1 and AMPK signalling pathways acting as adaptive responses cellular stress like chemotherapy [64].

Concentration and administration time of DOXO were in agree with other previous preclinical studies of anthracycline-induced cardiotoxicity $[22,65]$; more in details, mice analysed through echocardiography after 10 days of treatment with DOXO to measure left ventricular systolic function, heart rate and cardiac output, were previously described $[65,66]$ and in accordance to the recommendations of the American Society of Echocardiography [67].

\section{Study limitations}

This study is characterized by some limitations; first, in the clinical scenario, DOXO-induced cardiotoxicity occurs also many years after chemotherapy, especially in young women with breast cancer; however, immediate (acute) cardiac and endothelial cellular damages are frequently diagnosed and are however clinically relevant. Here, we used a preclinical model of acute doxorubicin cardiotoxicity, in agree with previous published works of Tocchetti G et al. [20] where doxorubicin showed significant subclinical damages even after 10 days of treatment (reduced ventricular ejection fraction and acute inflammation). Second, unfortunately, we have not quantified circulating Troponin-T and BNP levels in mice due to unavailability of the kits, however further studies will be performed in order to analyze the effect of EMPA on circulating markers of cardiac damages during treatment with cardiotoxic drugs. Effects on EMPA on the AMPK expression should be investigated both in cellular and preclinical models [68-70]. Other studies will be performed with dapagliflozin or canagliflozin aimed to compare the beneficial effects of different SGLT-2i during treatment with doxorubicin.

\section{Clinical perspective}

Currently, there is a need of cardioprotective strategies in cancer patients treated with doxorubicin, considering its relevant cardiotoxicity [71]. Actually, angiotensin antagonists, statins, beta-blockers and nutraceuticals are under investigations but with no clinically significant beneficial effects. We believe that the systemic anti-inflammatory effects of EMPA and its beneficial properties on cardiac functions in preclinical models treated with doxorubicin may be of useful clinical significance in the primary prevention of heart damages from anthracyclines.

\section{Conclusion}

The present study identified the mechanism whereby EMPA exerts anti-inflammatory and cardioprotective effects in DOXO-induced cardiotoxicity, thereby providing a new therapeutic option for patients undergoing anthracycline-based therapy.

\footnotetext{
(See figure on next page.)

Fig. 6 Cardiac function studies in mice treated with saline solution (Sham), EMPA $10 \mathrm{mg} / \mathrm{kg} /$ day, DOXO $2.17 \mathrm{mg} / \mathrm{kg} /$ day or EMPA plus DOXO ( $\mathrm{n}=6$ for each group). Cardiac function parameters IVS;d-D (mm), LVID;d-D (mm), LVID;s-D (mm), LVPW;d-D (mm), EF (\%), FS (\%), LV Mass (mg), LV Vol; d ( $\mu l)$ ), LV Vol; $s(\mu l)$ were determined through non-invasive transthoracic echocardiography Vevo 2100. (two-way ANOVA with a Bonferroni post hoc test). Values are expressed \pm SD. ${ }^{* * *} P<0.001 ;{ }^{* *} P<0.01 ;{ }^{*} P<0.05 ;$ ns: not significant
} 

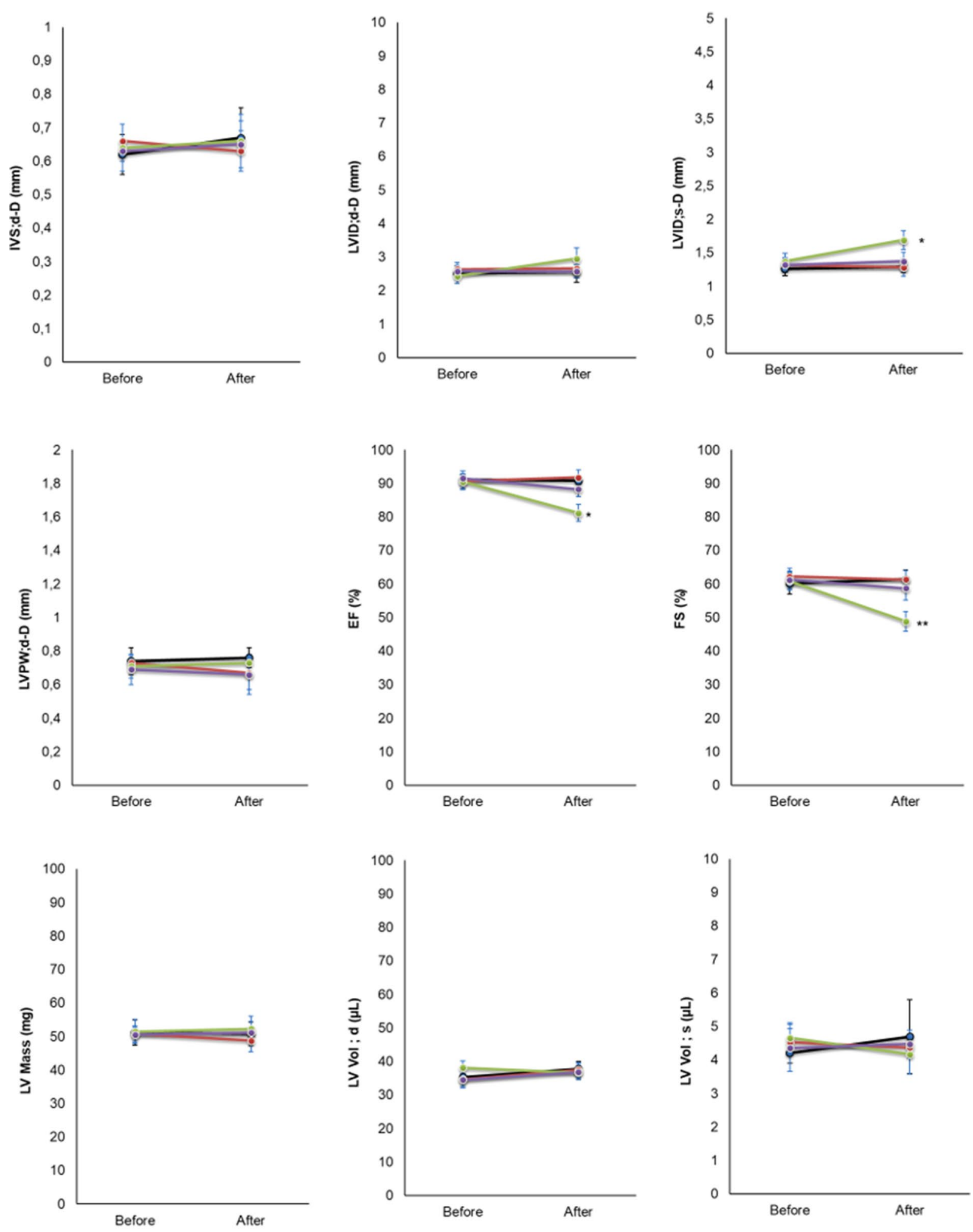

Fig. 6 (See legend on previous page.) 


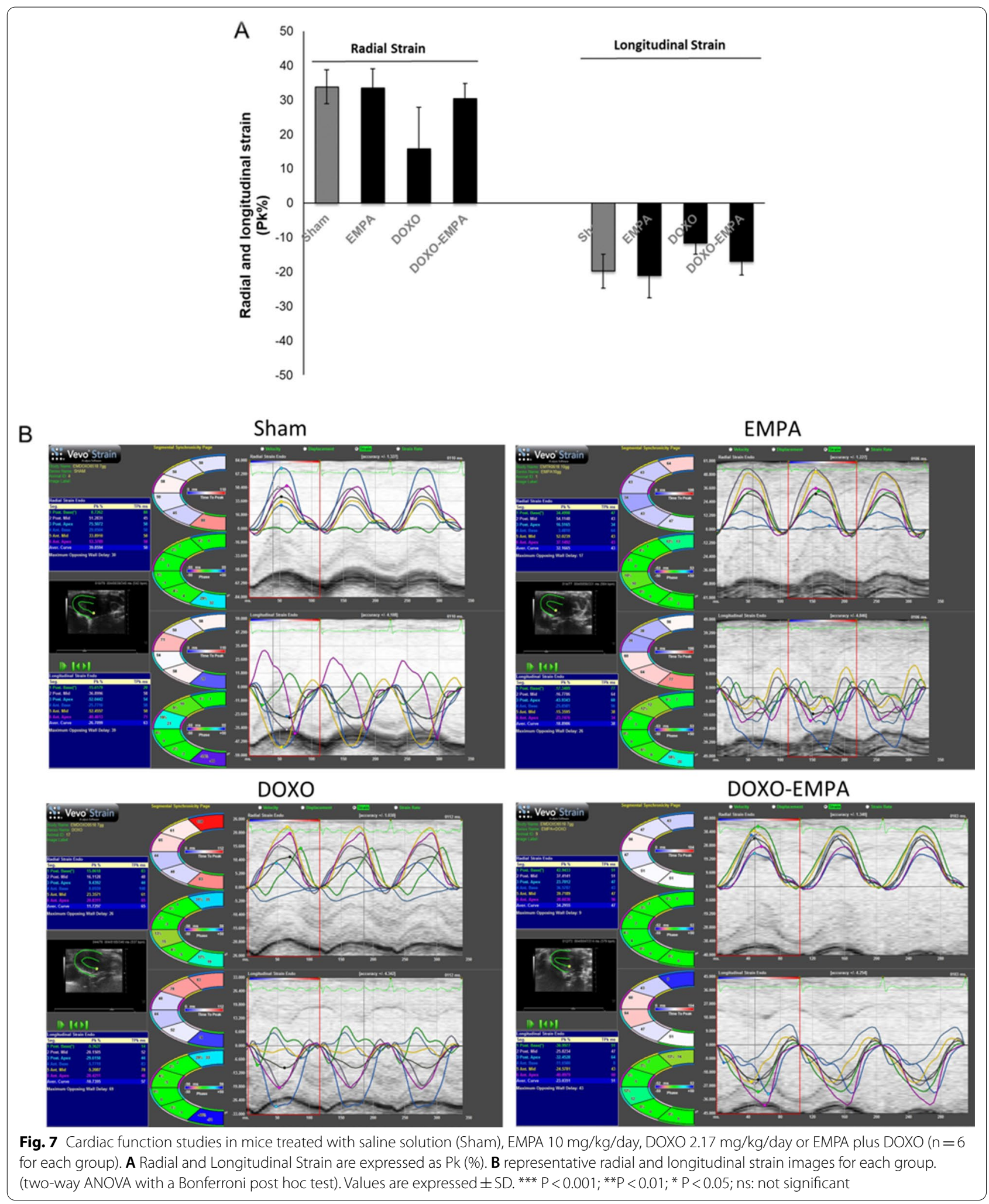




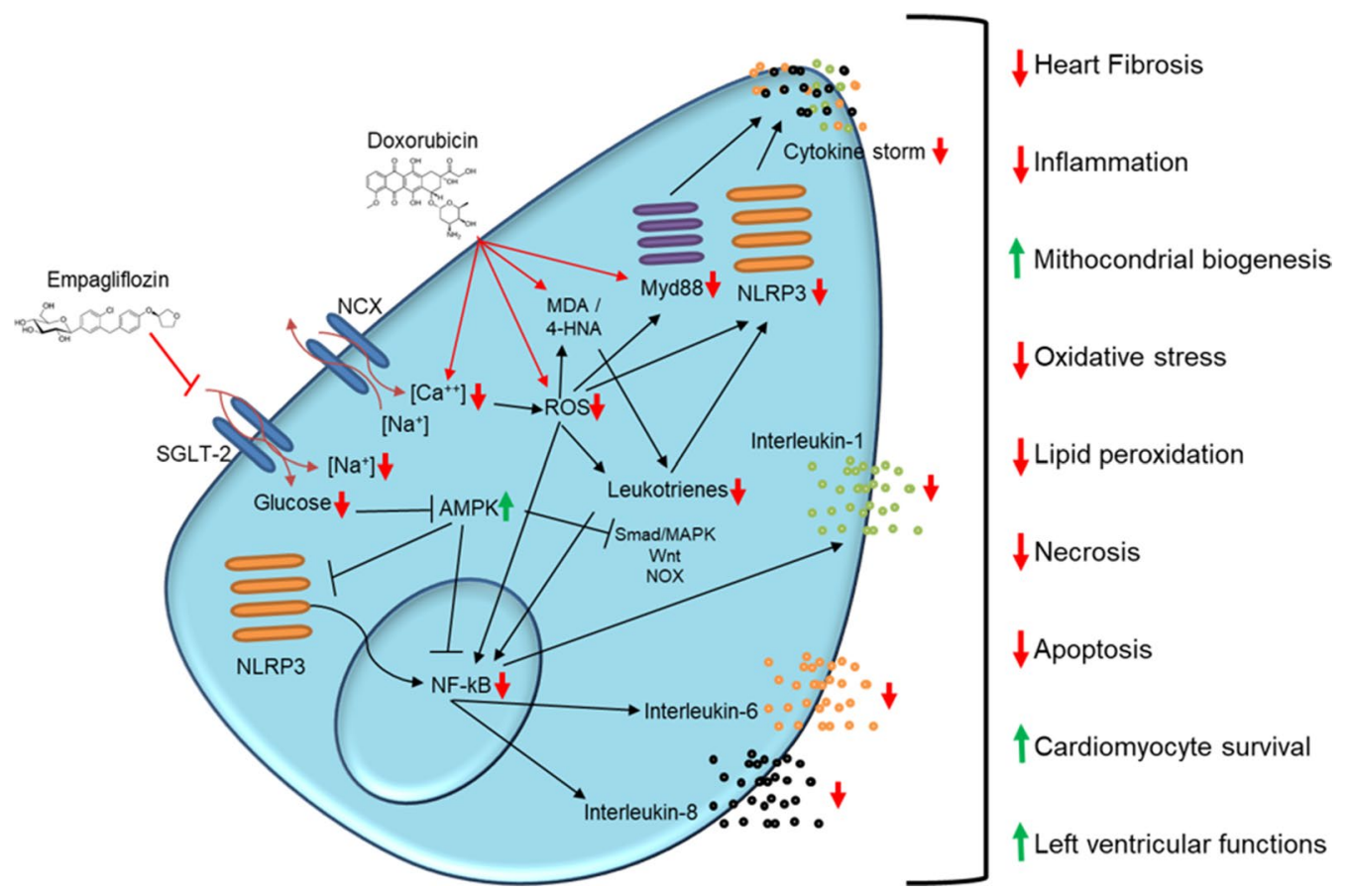

Fig. 8 Putative mechanisms of action of EMPA against doxorubicin-induced cardiotoxicity. EMPA inhibits the activity of SGLT-2 thereby reducing intracellular glucose and sodium in cardiomyocytes, resulting in the inhibition of iROS, lipid peroxidation and NLRP3/MyD88-related pathways; the inhibition of NLRP3 and NF-kB reduces the pro-inflammatory cytokine storm in cardiomyocytes exposed to DOXO

The cardioprotective effects of EMPA are biochemically explained by an improvement of the myocardial pro-inflammatory microenvironment and a reduced pro-oxidative state. This study provides the proof of concept for translational studies designed to investigate the cardioprotective use of EMPA during treatments with doxorubicin in cancer patients.

\section{Abbreviations}

DOXO: Doxorubicin; DOXO + EMPA: Doxorubicin plus EMPA; LV: Left ventricular; EF: Ejection fraction; LS: Longitudinal strain; EMPA: EMPA; SGLT-2i: Selective inhibitor of the sodium glucose co-transporter 2; FS: Fractional shortening; SD: Standard deviations; RS: Radial strain; NHE: Na +/H + exchanger; iROS: Intracellular reactive oxygen species; MDA: Malondialdehyde; 4HNA: 4-Hydroxy-nonenoic acid; NLRP3: NOD-, LRR- and pyrin domain-containing protein 3; MyD88 Myddosome type 88.

\section{Acknowledgements}

The authors thank Jean Ann Gilder (Scientific Communication srl., Naples, Italy) for language editing.

\section{Authors' contributions}

NM and VQ came up with the research idea, study design, and concept. $V Q, A B, A C, D R$, and $G M$ performed experiments. $G B$ and $N M$ analysed and interpreted data. VQ, DR, and NM wrote the manuscript and the other authors critically reviewed it. MC and LA performed western blot and gene expression experiments. MD and NM supervised all aspects of this study, including design, execution, and interpretation of the data. All authors have read and approved the final manuscript.

\section{Funding}

This work was funded by an "Ricerca Corrente" grant from the Italian Ministry of Health.

\section{Availability of data and materials}

The data used and/or analysed during the current study are available from the corresponding author on reasonable request.

\section{Declarations}

Ethics approval and consent to participate

Not applicable.

\section{Consent for publication}

Not applicable.

\section{Competing interests}

All the authors declare no conflict of interests.

\section{Author details}

${ }^{1}$ Division of Cardiology, Istituto Nazionale Tumori-IRCCS-Fondazione G Pascale, Naples, Italy. ${ }^{2}$ Breast Unit, Istituto Nazionale Tumori-IRCCS-Fondazione G. Pascale, Naples, Italy. ${ }^{3}$ SSD Sperimentazione Animale, Istituto Nazionale Tumori-IRCCS-Fondazione G. Pascale, Naples, Italy. ${ }^{4}$ Department of Translational Medical Sciences, University of Naples "Federico II", Naples, Italy. ${ }^{5}$ Department of Precision Medicine, University of Campania 'Luigi Vanvitelli', Via L. De Crecchio 7, 80138 Naples, Italy. ${ }^{6}$ Cardiology Division, Azienda USL Toscana Nord-Ovest, Versilia Hospital, Lido Di Camaiore, Italy. ${ }^{7}$ Scientific Direction, Istituto Nazionale Tumori-IRCCS-Fondazione G. Pascale, Naples, Italy.

Received: 15 February 2021 Accepted: 16 July 2021

Published online: 23 July 2021 


\section{References}

1. Baxter-Holland M, Dass CR. Doxorubicin, mesenchymal stem cell toxicity and antitumour activity: implications for clinical use. J Pharm Pharmacol. 2018;70(3):320-7. https://doi.org/10.1111/jphp.12869.

2. Mascarenhas L, Malogolowkin M, Armenian SH, Sposto R, Venkatramani R. A phase I study of oxaliplatin and doxorubicin in pediatric patients with relapsed or refractory extracranial non-hematopoietic solid tumors. Pediatr Blood Cancer. 2013;60(7):1103-7. https://doi.org/10.1002/pbc. 24471.

3. Khouri MG, Douglas PS, Mackey JR, Martin M, Scott JM, Scherrer-Crosbie $M$, Jones LW. Cancer therapy-induced cardiac toxicity in early breast cancer: addressing the unresolved issues. Circulation. 2012;126:2749-3276.

4. Mele D, Tocchetti CG, Pagliaro P, Madonna R, Novo G, Pepe A, Zito C, Maurea N, Spallarossa P. Pathophysiology of anthracycline cardiotoxicity. J Cardiovasc Med. 2016;17(Suppl 1):e3-11.

5. Rea D, Coppola C, Barbieri A, Monti MG, Misso G, Palma G, Bimonte S, Zarone MR, Luciano A, Liccardo D, Maiolino P, Cittadini A, Ciliberto G, Arra C. Maurea N. Strain analysis in the assessment of a mouse model of cardiotoxicity due to chemotherapy: sample for preclinical research. In Vivo. 2016:30(3):279-90.

6. White JR Jr. EMPA, an SGLT2 inhibitor for the treatment of type 2 diabetes mellitus: a review of the evidence. Ann Pharmacother. 2015:49(5):582-98. https://doi.org/10.1177/1060028015573564

7. Muscelli E, Astiarraga B, Barsotti E, Mari A, Schliess F, Nosek L, Heise T, Broedl UC, Woerle HJ, Ferrannini E. Metabolic consequences of acute and chronic EMPA administration in treatment-naive and metformin pretreated patients with type 2 diabetes. Diabetologia. 2016;59(4):700-8. https://doi.org/10.1007/s00125-015-3845-8.

8. Zinman B, Wanner C, Lachin JM, Fitchett D, Bluhmki E, Hantel S, Mattheus M, Devins T, Johansen OE, Woerle HJ, Broedl UC, Inzucchi SE. EMPA-REG outcome investigators. EMPA, Cardiovascular Outcomes, and Mortality in Type 2 Diabetes. N Engl J Med. 2015;373(22):2117-28. https://doi.org/10. 1056/NEJMoa1504720.

9. Zinman B, Inzucchi SE, Wanner C, Hehnke U, George JT, Johansen OE, Fitchett D. EMPA in women with type 2 diabetes and cardiovascular disease - an analysis of EMPA-REG OUTCOME ${ }^{\circledR}$. Diabetologia. 2018;61(7):1522-7. https://doi.org/10.1007/s00125-018-4630-2.

10. Cavero-Redondo I, Peleteiro B, Álvarez-Bueno C, Rodriguez-Artalejo F, Martínez-Vizcaíno V. Glycated haemoglobin A1c as a risk factor of cardiovascular outcomes and all-cause mortality in diabetic and nondiabetic populations: a systematic review and meta-analysis. BMJ Open 2017:7(7):e015949. https://doi.org/10.1136/bmjopen-2017-015949.

11. Packer M, Anker SD, Butler J, Filippatos G, Pocock SJ, Carson P, Januzzi J, Verma S, Tsutsui H, Brueckmann M, Jamal W, Kimura K, Schnee J, Zeller C, Cotton D, Bocchi E, Böhm M, Choi DJ, Chopra V, Chuquiure E, Giannetti N, Janssens S, Zhang J, Gonzalez Juanatey JR, Kaul S, Brunner-La Rocca HP, Merkely B, Nicholls SJ, Perrone S, Pina I, Ponikowski P, Sattar N, Senni M, Seronde MF, Spinar J, Squire I, Taddei S, Wanner C, Zannad F. Cardiovascular and renal outcomes with EMPA in heart failure. N Engl J Med. 2020 https://doi.org/10.1056/NEJMoa2022190.

12. Quagliariello V, Vecchione R, Coppola C, Di Cicco C, De Capua A, Piscopo G, Paciello R, Narciso V, Formisano C, Taglialatela-Scafati O, laffaioli RV, Botti G, Netti PA, Maurea N. Cardioprotective effects of nanoemulsions loaded with anti-inflammatory nutraceuticals against doxorubicininduced cardiotoxicity. Nutrients. 2018;10(9):1304. https://doi.org/10. 3390/nu10091304.

13. Barbarisi M, laffaioli RV, Armenia E, Schiavo L, De Sena G, Tafuto S, Barbarisi A, Quagliariello V. Novel nanohydrogel of hyaluronic acid loaded with quercetin alone and in combination with temozolomide as new therapeutic tool, CD44 targeted based, of glioblastoma multiforme. J Cell Physiol. 2018;233(10):6550-64. https://doi.org/10.1002/jcp.26238.

14. Darrabie MD, Arciniegas AJ, Mantilla JG, Mishra R, Vera MP, Santacruz L, Jacobs DO. Exposing cardiomyocytes to subclinical concentrations of doxorubicin rapidly reduces their creatine transport. Am J Physiol Heart Circ Physiol. 2012;303(5):H539-48. https://doi.org/10.1152/ajpheart. 00108.2012

15. Greene RF, Collins JM, Jenkins JF, Speyer JL, Myers CE. Plasma pharmacokinetics of adriamycin and adriamycinol: implications for the design of in vitro experiments and treatment protocols. Cancer Res. 1983;43:3417-21.
16. Quagliariello V, laffaioli RV, Armenia E, Clemente O, Barbarisi M, Nasti G, Berretta M, Ottaiano A, Barbarisi A. Hyaluronic acid nanohydrogel loaded with quercetin alone or in combination to a macrolide derivative of rapamycin RAD001 (Everolimus) as a new treatment for hormone-responsive human breast cancer. J Cell Physiol. 2017;232(8):2063-74.

17. Kim H, Park GS, Lee JE, Kim JH. A leukotriene B4 receptor-2 is associated with paclitaxel resistance in MCF-7/DOX breast cancer cells. Br J Cancer. 2013d;109(2):351-9. https://doi.org/10.1038/bjc.2013.333.

18. Nakabayashi H, Shimizu K. Involvement of Akt/NF-kB pathway in antitumor effects of parthenolide on glioblastoma cells in vitro and in vivo. BMC Cancer. 2012;5(12):453. https://doi.org/10.1186/1471-2407-12-453.

19. Di Stadio CS, Altieri F, Miselli G, Elce A, Severino V, Chambery A, Quagliariello V, Villano V, de Dominicis G, Rippa E, Arcari P. AMP18 interacts with the anion exchanger SLC26A3 and enhances its expression in gastric cancer cells. Biochimie. 2016;121:151-60. https://doi.org/10.1016/j.biochi. 2015.12.010.

20. Tocchetti CG, Carpi A, Coppola C, Quintavalle C, Rea D, Campesan M, Arcari A, Piscopo G, Cipresso C, Monti MG, De Lorenzo C, Arra C, Condorelli G, Di Lisa F, Maurea N. Ranolazine protects from doxorubicininduced oxidative stress and cardiac dysfunction. Eur J Heart Fail. 2014;16(4):358-66. https://doi.org/10.1002/ejhf.50.

21. Coppola C, Riccio G, Barbieri A, Monti MG, Piscopo G, Rea D, Arra C, Maurea C, De Lorenzo C, Maurea N. Antineoplastic-related cardiotoxicity, morphofunctional aspects in a murine model: contribution of the new tool 2D-speckle tracking. Onco Targets Ther. 2016;2(9):6785-94. https:// doi.org/10.2147/OTT.S106528.

22. Fedele C, Riccio G, Coppola C, Barbieri A, Monti MG, Arra C, Tocchetti CG, D'Alessio G, Maurea N, De Lorenzo C. Comparison of preclinical cardiotoxic effects of different ErbB2 inhibitors. Breast Cancer Res Treat. 2012;133(2):511-21. https://doi.org/10.1007/s10549-011-1783-9.

23. Riccio G, Antonucci S, Coppola C, D'Avino C, Piscopo G, Fiore D, Maurea C, Russo M, Rea D, Arra C, Condorelli G, Di Lisa F, Tocchetti CG, De Lorenzo C, Maurea N. Ranolazine attenuates trastuzumab-induced heart dysfunction by modulating ROS production. Front Physiol. 2018;9:38. https://doi.org/ 10.3389/fphys.2018.00038.

24. Pistner A, Belmonte S, Coulthard T, Blaxall B. Murine echocardiography and ultrasound imaging. J Vis Exp. 2010;42:2100. https://doi.org/10.3791/ 2100.

25 Tee N, Gu Y, Shim W. Comparative myocardial deformation in 3 myocardial layers in mice by speckle tracking echocardiography. Biomed Res Int 2015;2015:148501. https://doi.org/10.1155/2015/148501.

26. Donner DG, Kiriazis H, Du XJ, Marwick TH, McMullen JR. Improving the quality of preclinical research echocardiography: observations, training, and guidelines for measurement. Am J Physiol Heart Circ Physiol. 2018;315(1):H58-70. https://doi.org/10.1152/ajpheart.00157.2018.

27. de Lucia C, Wallner M, Eaton DM, Zhao H, Houser SR, Koch WJ. Echocardiographic strain analysis for the early detection of left ventricular systolic/ diastolic dysfunction and dyssynchrony in a mouse model of physiological aging. J Gerontol A Biol Sci Med Sci. 2019;74(4):455-61. https://doi. org/10.1093/gerona/gly139.

28. https://www.biotech.cornell.edu/sites/default/files/202006/Vevo\% 202100\%20Echocardiography.pdf.

29. Ichikawa Y, Ghanefar M, Bayeva M, Wu R, Khechaduri A, Naga Prasad SV, Mutharasan RK, Naik TJ, Ardehali H. Cardiotoxicity of doxorubicin is mediated through mitochondrial iron accumulation. J Clin Invest. 2014;124(2):617-30. https://doi.org/10.1172/JCI72931.

30. Fang X, Wang H, Han D, Xie E, Yang X, Wei J, Gu S, Gao F, Zhu N, Yin X, Cheng Q, Zhang P, Dai W, Chen J, Yang F, Yang HT, Linkermann A, Gu W, Min J, Wang F. Ferroptosis as a target for protection against cardiomyopathy. Proc Natl Acad Sci USA. 2019;116(7):2672-80. https://doi.org/10. 1073/pnas.1821022116

31. Tanaka Y, Nagoshi T, Yoshii A, Oi Y, Takahashi H, Kimura H, Ito K, Kashiwagi Y, Tanaka TD, Yoshimura M. Xanthine oxidase inhibition attenuates doxorubicin-induced cardiotoxicity in mice. Free Radic Biol Med. 2021;162:298-308. https://doi.org/10.1016/j.freeradbiomed.2020.10.303.

32. Sabatino J, De Rosa $S$, Tammè $L$, laconetti $C$, Sorrentino S, Polimeni $A$, Mignogna C, Amorosi A, Spaccarotella C, Yasuda M, Indolfi C. EMPA prevents doxorubicin-induced myocardial dysfunction. Cardiovasc Diabetol. 2020;19(1):66. https://doi.org/10.1186/s12933-020-01040-5.

33. Yoshii A, Nagoshi T, Kashiwagi Y, Kimura H, Tanaka Y, Oi Y, Ito K, Yoshino T, Tanaka TD, Yoshimura M. Cardiac ischemia-reperfusion injury under 
insulin-resistant conditions: SGLT1 but not SGLT2 plays a compensatory protective role in diet-induced obesity. Cardiovasc Diabetol. 2019;18(1):85. https://doi.org/10.1186/s12933-019-0889-y.

34 Eliaa SG, Al-Karmalawy AA, Saleh RM, Elshal MF. EMPA and doxorubicin synergistically inhibit the survival of triple-negative breast cancer cells via interfering with the mTOR pathway and inhibition of calmodulin: in vitro and molecular docking studies. ACS Pharmacol Transl Sci. 2020;3(6):13308. https://doi.org/10.1021/acsptsci.0c00144.

35. Sayed-Ahmed MM, Khattab MM, Gad MZ, Osman AM. Increased plasma endothelin-1 and cardiac nitric oxide during doxorubicin-induced cardiomyopathy. Pharmacol Toxicol. 2001;89(3):140-4.

36. Aldieri E, Bergandi L, Riganti C, Costamagna C, Bosia A, Ghigo D. Doxorubicin induces an increase of nitric oxide synthesis in rat cardiac cells that is inhibited by iron supplementation. Toxicol Appl Pharmacol. 2002;185(2):85-90.

37. Bacchiega BC, Bacchiega AB, Usnayo MJ, Bedirian R, Singh G, Pinheiro GD. Interleukin 6 inhibition and coronary artery disease in a high-risk population: a prospective community-based clinical study. J Am Heart Assoc. 2017;6(3):e005038. https://doi.org/10.1161/JAHA.116.005038.

38. Pecoraro M, Del Pizzo M, Marzocco S, Sorrentino R, Ciccarelli M, laccarino G, Pinto A, Popolo A. Inflammatory mediators in a short-time mouse model of doxorubicin-induced cardiotoxicity. Toxicol Appl Pharmacol. 2016;15(293):44-52. https://doi.org/10.1016/j.taap.2016.01.006.

39. Andreadou I, Efentakis P, Balafas E, Togliatto G, Davos CH, Varela A, Dimitriou CA, Nikolaou PE, Maratou E, Lambadiari V, Ikonomidis I, Kostomitsopoulos N, Brizzi MF, Dimitriadis G, Iliodromitis EK. EMPA limits myocardial infarction in vivo and cell death in vitro: role of STAT3, mitochondria, and redox aspects. Front Physiol. 2017;8:1077. https:// doi.org/10.3389/fphys.2017.01077.

40. Arciniegas Calle MC, Sandhu NP, Xia H, Cha SS, Pellikka PA, Ye Z, Herrmann J, Villarraga HR. Two-dimensional speckle tracking echocardiography predicts early subclinical cardiotoxicity associated with anthracycline-trastuzumab chemotherapy in patients with breast cancer. BMC Cancer. 2018;18(1):1037. https://doi.org/10.1186/s12885-018-4935-z.

41. Sawaya H, Sebag IA, Plana JC, Januzzi JL, Ky B, Tan TC, Cohen V, Banchs J, Carver JR, Wiegers SE, Martin RP, Picard MH, Gerszten RE, Halpern EF, Passeri J, Kuter I, Scherrer-Crosbie M, Sawaya H, Sebag IA, Plana JC, Januzzi JL, Ky B, Cohen V, Gosavi S, Carver JR, Wiegers SE, Martin RP, Picard MH, Gerszten RE, Halpern EF, Passeri J, Kuter I, Scherrer-Crosbie M. Assessment of echocardiography and biomarkers for the extended prediction of cardiotoxicity in patients treated with anthracyclines, taxanes, and trastuzumab. Circ Cardiovasc Imaging. 2012;5(5):596-603.

42. Sawaya H, Sebag IA, Plana JC, Januzzi JL, Ky B, Cohen V, Gosavi S, Carver $J R$, Wiegers SE, Martin RP, Picard MH. Early detection and prediction of cardiotoxicity in chemotherapy-treated patients. Am J Cardiol. 2011:107:1375-80.

43. Sawaya H, Sebag IA, Plana JC, Januzzi JL, Ky B, Tan TC, Cohen V, Banchs J, Carver JR, Wiegers SE, Martin RP, Picard MH, Gerszten RE, Halpern EF, Passeri J, Kuter I, Scherrer-Crosbie M. Assessment of echocardiography and biomarkers for the extended prediction of cardiotoxicity in patients treated with anthracyclines, taxanes, and trastuzumab. Circ Cardiovasc Imaging. 2012;5(5):596-603.

44. Fitchett D, Butler J, van de Borne P, Zinman B, Lachin JM, Wanner C, Woerle HJ, Hantel S, George JT, Johansen OE, Inzucchi SE. Effects of EMPA on risk for cardiovascular death and heart failure hospitalization across the spectrum of heart failure risk in the EMPA-REG OUTCOME ${ }^{\circledR}$ trial. Eur Heart J. 2018;39(5):363-70. https://doi.org/10.1093/eurheartj/ ehx511.

45. Wang L, Chen Q, Qi H, Wang C, Wang C, Zhang J, Dong L. Doxorubicininduced systemic inflammation is driven by upregulation of toll-like receptor TLR4 and endotoxin leakage. Cancer Res. 2016;76(22):663142. https://doi.org/10.1158/0008-5472.CAN-15-3034.

46 Lyu YL, Kerrigan JE, Lin CP, Azarova AM, Tsai YC, Ban Y, Liu LF. Topoisomerase Ilbeta mediated DNA double-strand breaks: implications in doxorubicin cardiotoxicity and prevention by dexrazoxane. Cancer Res. 2007:67(18):8839-46. https://doi.org/10.1158/0008-5472.CAN-07-1649.

47. Ng KM, Lau YM, Dhandhania V, Cai ZJ, Lee YK, Lai WH, Tse HF, Siu C. EMPA ammeliorates high glucose induced-cardiac dysfuntion in human iPSC-derived cardiomyocytes. Sci Rep. 2018;8(1):14872. https:// doi.org/10.1038/s41598-018-33293-2.
48. Baartscheer A, Schumacher CA, Wust RC, Fiolet JW, Stienen GJ, Coronel $\mathrm{R}$, Zuurbier CJ. EMPA decreases myocardial cytoplasmic Na+ through inhibition of the cardiac $\mathrm{Na}+/ \mathrm{H}+$ exchanger in rats and rabbits. Diabetologia. 2017;60:568-73.

49. Mele D, Tocchetti CG, Pagliaro P, Madonna R, Novo G, Pepe A, Zito C, Maurea N, Spallarossa P. Pathophysiology of anthracycline cardiotoxicity. J Cardiovasc Med. 2016;17(Suppl 1):S3-11. https://doi.org/10.2459/ JCM.0000000000000378.Review.

50. Hrelia S, Fiorentini D, Maraldi T, Angeloni C, Bordoni A, Biagi PL, Hakim G. Doxorubicin induces early lipid peroxidation associated with changes in glucose transport in cultured cardiomyocytes. Biochim Biophys Acta. 2002;1567(1-2):150-6.

51. Li C, Zhang J, Xue M, Li X, Han F, Liu X, Xu L, Lu Y, Cheng Y, Li T, Yu X, Sun B, Chen L. SGLT2 inhibition with EMPA attenuates myocardial oxidative stress and fibrosis in diabetic mice heart. Cardiovasc Diabetol. 2019;18(1):15. https://doi.org/10.1186/s12933-019-0816-2.

52. Pabel S, Wagner S, Bollenberg H, Bengel P, Kovács Á, Schach C, Tirilomis P, Mustroph J, Renner A, Gummert J, Fischer T, Van Linthout S, Tschöpe C, Streckfuss-Bömeke K, Hasenfuss G, Maier LS, Hamdani N, Sossalla S. EMPA directly improves diastolic function in human heart failure. Eur J Heart Fail. 2018;20(12):1690-700. https://doi.org/10.1002/ejhf.1328.

53. Octavia Y, Tocchetti CG, Gabrielson KL, Janssens S, Crijns HJ, Moens AL. Doxorubicin-induced cardiomyopathy: from molecular mechanisms to therapeutic strategies. J Mol Cell Cardiol. 2012;52(6):1213-25. https:// doi.org/10.1016/j.yjmcc.2012.03.006.

54. Guerra J, De Jesus A, Santiago-Borrero P, Roman-Franco A, Rodríguez $\mathrm{E}$, Crespo MJ. Plasma nitric oxide levels used as an indicator of doxorubicin-induced cardiotoxicity in rats. Hematol J. 2005;5(7):584-8.

55 Kalivendi SV, Kotamraju S, Zhao H, Joseph J, Kalyanaraman B. Doxorubicin-induced apoptosis is associated with increased transcription of endothelial nitric-oxide synthase. Effect of antiapoptotic antioxidants and calcium. J Biol Chem. 2001;276(50):47266-76.

56. Han X, Zhou Y, Liu W. Precision cardio-oncology: understanding the cardiotoxicity of cancer therapy. NPJ Precis Oncol. 2017;1 (1):31. https:// doi.org/10.1038/s41698-017-0034-x.

57. Zhu J, Zhang J, Zhang L, Du R, Xiang D, Wu M, Zhang R, Han W. Interleukin-1 signaling mediates acute doxorubicin-induced cardiotoxicity. Biomed Pharmacother. 2011;65(7):481-5. https://doi.org/10.1016/j. biopha.2011.06.005.

58. Sauter KA, Wood LJ, Wong J, lordanov M, Magun BE. Doxorubicin and daunorubicin induce processing and release of interleukin-1 $\beta$ through activation of the NLRP3 inflammasome. Cancer Biol Ther. 2011;11(12):1008-16.

59. Zhu J, Zhang J, Xiang D, Zhang Z, Zhang L, Wu M, Zhu S, Zhang R, Han W. Recombinant human interleukin-1 receptor antagonist protects mice against acute doxorubicin-induced cardiotoxicity. Eur J Pharmacol. 2010;643(2-3):247-53.

60 Apostolakis S, Vogiatzi K, Amanatidou V, Spandidos DA. Interleukin 8 and cardiovascular disease. Cardiovasc Res. 2009;84(3):353-60. https:// doi.org/10.1093/cvr/cvp241.

61. Timm KN, Tyler DJ. The role of AMPK activation for cardioprotection in doxorubicin-induced cardiotoxicity. Cardiovasc Drugs Ther. 2020;34(2):255-69. https://doi.org/10.1007/s10557-020-06941-x.

62. Oh CM, Cho S, Jang JY, Kim H, Chun S, Choi M, Park S, Ko YG. Cardioprotective potential of an SGLT2 inhibitor against doxorubicin-induced heart failure. Korean Circ J. 2019;49(12):1183-95. https://doi.org/10. 4070/kcj.2019.0180.

63. Yang CC, Chen YT, Wallace CG, Chen KH, Cheng BC, Sung PH, Li YC, Ko SF, Chang HW, Yip HK. Early administration of EMPA preserved heart function in cardiorenal syndrome in rat. Biomed Pharmacother. 2019;109:658-70. https://doi.org/10.1016/j.biopha.2018.10.095.

64. Packer M. SGLT2 inhibitors produce cardiorenal benefits by promoting adaptive cellular reprogramming to induce a state of fasting mimicry: a paradigm shift in understanding their mechanism of action. Diabetes Care. 2020;43(3):508-11. https://doi.org/10.2337/dci19-0074.

65. Toldo S, Goehe RW, Lotrionte M, Mezzaroma E, Sumner ET, Biondi-Zoccai GG, Seropian IM, Van Tassell BW, Loperfido F, Palazzoni G, Voelkel NF, Abbate A, Gewirtz DA. Comparative cardiac toxicity of anthracyclines in vitro and in vivo in the mouse. PLoS ONE. 2013;8(3):e58421.

66. Toldo S, Bogaard HJ, Van Tassell BW, Mezzaroma E, Seropian IM, et al. Right ventricular dysfunction following acute myocardial infarction 
in the absence of pulmonary hypertension in the mouse. PLoS ONE. 2011;6:e18102.

67. Gardin JM, Adams DB, Douglas PS, Feigenbaum H, Forst DH, et al. Recommendations for a standardized report for adult transthoracic echocardiography: a report from the American Society of Echocardiography's Nomenclature and Standards Committee and Task Force for a Standardized Echocardiography Report. J Am Soc Echocardiogr. 2002;15:275-90.

68. Romera I, Ampudia-Blasco FJ, Pérez A, Ariño B, Pfarr E, Giljanovic Kis S, Naderali E. Efficacy and safety of EMPA in combination with other oral hypoglycemic agents in patients with type 2 diabetes mellitus. Endocrinol Nutr. 2016;63(10):519-26. https://doi.org/10.1016/j.endonu. 2016.06.003.

69. Dekkers CCJ, Gansevoort RT. Sodium-glucose cotransporter 2 inhibitors: extending the indication to non-diabetic kidney disease? Nephrol Dial Transplant. 2020;35(Suppl 1):i33-42. https://doi.org/10.1093/ndt/ gfz264.
70. Santos-Gallego CG, Vargas-Delgado AP, Requena-Ibanez JA, GarciaRopero A, Mancini D, Pinney S, Macaluso F, Sartori S, Roque M, SabatelPerez F, Rodriguez-Cordero A, Zafar MU, Fergus I, Atallah-Lajam F, Contreras JP, Varley C, Moreno PR, Abascal VM, Lala A, Tamler R, Sanz J, Fuster V, Badimon JJ. Randomized trial of EMPA in nondiabetic patients with heart failure and reduced ejection fraction. J Am Coll Cardiol. 2021;77(3):243-55. https://doi.org/10.1016/j.jacc.2020.11.008.

71. Maurea N, Coppola C, Piscopo G, Galletta F, Riccio G, Esposito E, De Lorenzo C, De Laurentiis M, Spallarossa P, Mercuro G. Pathophysiology of cardiotoxicity from target therapy and angiogenesis inhibitors. J Cardiovasc Med. 2016;17(Suppl 1):e19-26.

\section{Publisher's Note}

Springer Nature remains neutral with regard to jurisdictional claims in published maps and institutional affiliations.
Ready to submit your research? Choose BMC and benefit from:

- fast, convenient online submission

- thorough peer review by experienced researchers in your field

- rapid publication on acceptance

- support for research data, including large and complex data types

- gold Open Access which fosters wider collaboration and increased citations

- maximum visibility for your research: over 100M website views per year

At BMC, research is always in progress.

Learn more biomedcentral.com/submissions 